\title{
RELEVANCIA DE LA SEDE ARBITRAL Y CRITERIOS QUE DETERMINAN SU ELECCIÓN*
}

\section{IMPORTANCE OF ARBITRAL SEAT \\ AND CRITERIA \\ FOR VENUE SELECTION}

\section{RELEVÂNCIA DA SEDE ARBITRAL E CRITÉRIOS QUE DETERMINAM SUA SELEÇÃO}

María Fernanda Vásquez Palma**

\section{Resumen}

El presente trabajo revisa el tema de las sedes de arbitraje comerciales internacionales desde una óptica general, profundizando en el debate existente sobre su actual importancia y los criterios que debieran considerarse en su elección.

Palabras claves: sedes arbitraje comercial internacional, importancia, efectos, criterios.

* Este trabajo se inserta en el proyecto FONDECYT No 11090227, titulado "Chile como sede de arbitrajes comerciales internacionales. Oportunidades y amenazas para la implementación de la nueva ley de arbitraje comercial internacional, a la luz de la experiencia comparada", del que la autora es investigadora responsable. Agradezco al Instituto Max Planck por permitirme realizar una estancia de investigación en su sede de Hamburgo, que ha sido crucial para el desarrollo del presente artículo (noviembre de 2010-Alemania).

** Doctora en Derecho, Universidad Complutense de Madrid. Profesora de Derecho Comercial y Derecho Internacional Privado, Facultad de Ciencias Jurídicas y Sociales, Universidad de Talca. Dirección postal: avenida Lircay s/n, Universidad de Talca, Facultad de Ciencias Jurídicas y Sociales, Talca, Chile. Artículo recibido el 29 de septiembre de 2010 y aceptado para su publicación el 21 de marzo de 2011. Correo electrónico: mfvasquez@ utalca.cl 


\begin{abstract}
This paper reviews the topic of international commercial arbitration places from a general perspective, penetrating into the existing debate on his current importance and the criteria that must be considered in his choice.
\end{abstract}

Keywords: International commercial arbitration places, Importance, Effects, Criteria.

\title{
Resumo
}

O presente trabalho revisa o tema das sedes de arbitragem comerciais internacionais desde uma óptica geral, aprofundando no debate existente sobre sua atual importância e os critérios que deveriam ser considerados na sua seleção.

Palavras chaves: sedes arbitragem comercial internacional, importância, efeitos, critérios.

\section{INTRODUCCIÓN A LA PROBLEMÁTICA}

Superada la tendencia de desconfianza que impregnó durante años a las legislaciones latinoamericanas en materia de arbitraje ${ }^{1}$, la mayor parte de ellas, desde la década de 1990, se apresuró en fortalecerlo en el ámbito comercial internacional con el objetivo de brindar un marco jurídico adecuado y convertirse de paso en sedes arbitrales. En tal escenario, la adopción de una ley moderna constituía la llave para integrarse a este campo de acción y promover un ambiente favorable al uso del arbitraje como medio de

\footnotetext{
${ }^{1}$ Jean Kleinheinsterkamp, Internacional Commercial Arbitration in Latin América, United States of América, Oceana Publications, Inc., 200; Fernando Cantuarias Salaverry, "Problemática general de la práctica del arbitraje internacional en Latinoamérica", artículo presentado en el panel "Arbitration Developments in Latin América", New York State Bar Association, International Law and Practice Section, Santiago, nov. 2004, disponible en http://www.upc.edu.pe/bolson/0/0/3/33/142/FC6.doc; Marvin Goldman, "El arbitraje comercial en las Américas”, en Técnicas Financieras; vol. 8, mayo-junio, 1969, pp. 496-520 y Yaritza Pérez PACHeco, "Los aportes de la conferencia especializada interamericana sobre Derecho Internacional Privado en materia de arbitraje internacional", en Boletín Mexicano de Derecho Comparado, año XLI, No 121, enero-abril de 2008, pp. 357-384, quien da cuenta de la evolución del arbitraje en el sistema interamericano; J.L. SiQueIros, El arbitraje comercial internacional. La experiencia latinoamericana, México, Ed. Porrúa, 1999.
} 
solución de diferencias internacionales ${ }^{2}$. Tal actuar desató lo que se denominó una verdadera "fiebre" de arbitraje ${ }^{3}$ en dichas normativas, aunque sin seguir los mismos postulados ${ }^{4}$.

Chile no ha sido una excepción en la materia, pues desde hace algunos años decidió adherirse al modelo paradigmático existente sobre el arbitraje comercial internacional, a partir de la publicación de la ley $\mathrm{N}^{\circ} 19.971$ de $2004^{5}$, que sigue de cerca la LMU de $1985^{6}$. Esta norma fue creada por el legislador no sólo para llenar un vacío existente en esta materia sino, principalmente, con miras a convertirse en una importante sede arbitral en la región ${ }^{7}$. El primer objetivo se ha conseguido, sin lugar a dudas; el segundo, en cambio, no ha podido concretarse, pues, a pesar de la publicación de la ley, la realidad nos muestra que aún estamos lejos del pretendido sitial.

¿Qué necesita Chile para convertirse en una sede atractiva de arbitraje comercial internacional?, es la pregunta que emerge y la que nos hemos

${ }^{2}$ Sobre los intereses que motivaron esta modificación, véase, entre otros: Guillermo Palao Moreno, "Nuevas tendencias en materia de arbitraje comercial internacional en América Latina”, en S. BARONA VILA (coord.), Arbitraje y justicia en el siglo XXI, Madrid, 2007, pp. 212-213; Bernardo Cremades y David CAIrns, "El arbitraje en la encrucijada entre la globalización y sus detractores”, en $R C E A, 2002$, pp. 15-61. Sobre la acogida del arbitraje en Latinoamérica y los posibles puntos de fricción, véase Rubén SANTOS BELANDro, "Se ha instalado un provechoso quid quo en los Estados Latinoamericanos respecto del arbitraje", en Revista Vasca de Derecho Procesal y Arbitraje, tomo xvI, mayo 2004, pp. 427-433.

${ }^{3}$ México fue el primer país que adoptó la ley modelo de 1985 en 1993 (decreto de 1993 que modifica el Código de Comercio), luego lo harán Guatemala (decreto No 67 de 1995); Brasil (ley N 9.037 de 1996, sobre arbitraje); Costa Rica (ley N 7.727 de 1997, sobre resolución de conflictos y promoción de la paz social); Bolivia (ley $\mathrm{N}^{\mathrm{o}} 1.770$ de 1997 de arbitraje y conciliación); Ecuador (ley RO/145 de 1997);Venezuela (Ley de Arbitraje Comercial de 1998); Colombia (decreto $\mathrm{N}^{\mathrm{O}} 1818$ de 1998, por medio del cual se expide el estatuto de los mecanismos alternativos de resolución de disputas); Panamá (decreto No 5 de 1999, que establece el régimen general de arbitraje); El Salvador (decreto $N^{\circ} 914$ de 2002, Ley de Mediación, Conciliación y Arbitraje); Paraguay (ley No 1.879 de 2002, de medios de resolución de conflictos); Nicaragua (ley No 540 de 2005, Ley de Mediación y Arbitraje).

${ }^{4}$ Véase sitio CNUDMI: http://www.uncitral.org. Para Guillermo Palao Moreno, se podrían dividir las legislaciones entre aquéllas que siguen de cerca la LMU (Chile, Guatemala, México, Nicaragua), de las restantes que se ha distanciado sensiblemente de aquélla, (n. 2), pp. 215-216.

${ }^{5}$ Publicada en el Diario Oficial el 29 de septiembre de 2010.

${ }^{6}$ Véase http://www.uncitral.org/uncitral/es/uncitral_texts/arbitration/1985Model_ arbitratio.html.

${ }^{7}$ Véase historia de la ley $\mathrm{N}^{0} 19.971$ http://www.bcn.cl. A mayor abundamiento, debemos destacar el hecho de que Chile abriga desde hace un par de décadas una auspiciosa apertura económica internacional, suscribiendo a estos efectos sendos TLCs, APPIs y una generalidad de contratos comerciales internacionales, todos ellos con inclusión de cláusulas arbitrales, por lo que los resultados propuestos en esta investigación, serán cruciales para el desarrollo y confianza de esta institución en sede mercantil. 
propuesto responder en la presente investigación, que se conforma de dos partes conexas entre sí. La primera -que en esta oportunidad se presenta- tiene por objetivo efectuar un estudio de las sedes arbitrales desde un enfoque general que tienda a develar las principales problemáticas existentes en la materia ${ }^{8}$ y ciertos criterios de elegibilidad de las mismas que se han instaurado con el paso del tiempo. La primera advertencia que debemos hacer en tal sentido, es que no basta con poseer una ley de arbitraje comercial internacional moderna para ser una sede atractiva, si así fuese, la gran cantidad de países que cuentan con dichas legislaciones lo serían, y no es así.

El tema de las sedes arbitrales constituye un fenómeno complejo, toda vez que en él se incardina un conjunto vasto de temáticas que no pueden eludirse, como son las pugnas existentes entre las llamadas tesis de la localización y deslocalización del arbitraje, la validez de los laudos flotantes, la pertinencia y trascendencia de la nulidad de un laudo, efectuada por un Estado y su posible ejecución por otro, el abandono del método conflictual por la denominada ley material, la delimitación y concreción de la autonomía arbitral, entre otros. De este modo, antes de determinar los elementos que subyacen a una oferta atractiva de una sede arbitral, necesariamente debemos recorrer este sinuoso camino, estudiando el conjunto de materias relatadas, el que, además de contextualizar nuestro estudio, nos aportarán sustancia y fundamento en el desarrollo de nuestra investigación.

En la lógica planteada, el presente trabajo tendrá como objetivo principal poner a disposición de la comunidad jurídica una completa revisión de la temática del tema propuesto. En particular, se pretende analizar en profundidad dos tópicos concretos:

1. La importancia de la sede arbitral en la actualidad, ahondando en las discusiones y filosofías existentes en la materia y

2. Los criterios que deben considerarse en su elección, estudiando en profundidad las variables ligadas a la misma.

Concluiremos con algunas reflexiones que deben ser tenidas en cuenta en relación al papel que debiera cumplir la sede. Cada una de estas materias será tratada en el mismo orden señalado en los apartados que guían este escrito.

Nos proponemos realizar un estudio desde un enfoque primordialmente teórico, sin dejar por ello de indagar en algunos casos prácticos que, por

${ }^{8}$ De acuerdo con el proyecto trazado, en la segunda parte se realizará un estudio legislativo-comparado tanto de los países como de los Estados comúnmente calificados como atractivos en cuanto sede arbitral, considerando los elementos que aquí se detecten como relevantes a estos efectos. En él se posicionará la realidad chilena detectando las fortalezas y debilidades que existen para lograr este objetivo. 
su importancia, nos servirán para ilustrar el estado de la cuestión. Con todo, la relevancia de esta investigación podrá apreciarse en el futuro en el terreno fáctico si se logran dimensionar estos factores y extrapolarlos luego a nuestra realidad jurídica. En este sentido, los resultados de esta investigación servirán para efectuar acomodos tanto legislativos como de carácter jurisprudencial, que -como veremos- resultarán relevantes frente a los objetivos planteados en un inicio por el legislador. Desde esta óptica, la propuesta y enfoque aquí formulado es novedoso en tanto se hace cargo de plantear y responder problemas que no han sido mayormente tratados por la doctrina en general ${ }^{9}$ y la chilena en particular, hasta ahora ${ }^{10}$.

La metodología a emplear será la propia de la investigación jurídica. A partir del método analítico y sintético, revisaremos cada uno de los elementos que informan el problema objeto del presente estudio. A partir del método sistemático categorizaremos, agruparemos y ordenaremos el fenómeno en análisis. A través del exegético, analizaremos las disposiciones legales que rigen el instituto arbitral. El método comparado será crucial para dar valor a unas cuantas afirmaciones, considerando para ello lo planteado

${ }^{9}$ Por todos véase Jean Poudret y Sébastien Besson, Droit Comparé de l'arbitrage internationakl Schlthess, Zurich, 2002, pp. 83-119; Philips Fouchard, Emmanuel GaIllard, Goldman, “On International commercial arbitration”, in E. Gaillards y J. SAvage (eds.), Kluwer Law International, La Haya, 1999, pp. 78-93; Alan Redfenn y Martin Hunter, Law and practice of International commercial arbitration, $3^{\mathrm{a}}$ ed., Londres, Sweet \& Maxwell, 1999, pp. 283-292; Henry Álvarez, "La escogencia del lugar del arbitraje", en Revista Internacional de Arbitraje, No 3, Bogotá, 2005, pp. 13-16; Thomas ClaY, "La importancia de la sede de arbitraje en el arbitraje internacional: ¿es todavía relevante?, en Fernando MantillaSErrano (coord.), Arbitraje internacional. Tensiones actuales, Bogotá, Ed. Legis, 2007, pp.193194; José Carlos Fernández Rozas, "Determinación del lugar del arbitraje y consecuencias del control del laudo por el tribunal de la sede arbitral", en Lima-arbitration, $\mathrm{N}^{\circ} 2,2007$, pp. 25-62; P. LAVIVE, "On the neutrality of the arbitrator and the place of arbitration", en Swiss Essays on International Arbitration, Lausanne, 1984, pp. 23-33; Fernando Mantilla SERrano, "La autonomía del derecho del arbitraje internacional: chacia un arbitraje realmente autónomo?, en Fernando Mantilla-Serrano (coord.), Arbitraje internacional. Tensiones actuales, Bogotá, Ed. Legis, 2007; Neelanjan MaITRA, "Domestic Court Intervention in internacional Arbitration-The English View", in Journal of International Arbitration, vol. 23, No 3, 2006, pp. 239-248; Leonel Pereznieto \& James Graham, "La muerte programada del Estado sede del arbitraje”, en Revista Latinoamericana de Mediación y Arbitraje, México, 2006, pp. 197-208; Evelio Verdera y Tuells, "La elección del lugar y del idioma en el procedimiento arbitral”, en $R C E A, 1995$, pp. 89-102; $\mathrm{M}^{\mathrm{a}}$ Fernanda VÁsquez Palma, “¿Están preparados los países latinoamericanos para ser sedes de arbitrajes?”, en Revista Internacional de Arbitraje, No 10, enero-junio 2009, pp. 109-174; Eduardo Zuleta Jaramillo, "El reconocimiento y ejecución internacionales de laudos anulados", en Cámara de Comercio de Bogotá, No 7, Bogotá, 2002.

${ }^{10} \mathrm{Si}$ bien se ha vislumbrado parte de esta problemática, esto se ha hecho desde una perspectiva general. Ma Fernanda Vásquez Palma, Arbitraje en Chile. Análisis crítico de su normativa y jurisprudencia, Santiago, Ed. Legal Publishing, 2009, p. 50 y ss. 
por los regímenes jurídicos más avanzados en la materia. Concluiremos con el método hermenéutico y con la aplicación de la lógica jurídica para profundizar en cada uno de los problemas y soluciones propuestas.

\section{Dimensión General DE LAS SEDES ARbitrales}

\section{1. ¿Qué se entiende por sede arbitral?}

Desde una óptica general, el concepto de la sede del arbitraje ${ }^{11}$ es estrictamente jurídico ${ }^{12}$, en cuanto corresponde al lugar pactado por las partes para llevarlo a cabo. La calificación de "jurídico" contrasta con la dimensión práctica ${ }^{13}$, en tanto esta elección no implica que todas las actuaciones deban ser realizadas en dicho lugar ${ }^{14}$; por el contrario, el tribunal arbitral podrá realizar las diligencias en otros sitios ya sea a petición de las partes o por su propia iniciativa, si tiene facultades para ello ${ }^{15}$. Esta movilidad está recogida en el art. $20.2^{\circ}$ de la LMU y reproducida en la mayor parte de las legislaciones que siguen la LMU. Al efecto, el RAU distingue entre la posibilidad de celebrar reuniones y oír testigos en cualquier lugar que el tribunal estime conveniente, atendiendo a las circunstancias del arbitraje $\left(\right.$ art. $\left.16.2^{\circ}\right)$ y la eventualidad de inspeccionar mercancías y otros bienes o documentos, en cuyo caso, también es libre de reunirse en cualquier lugar, aunque para ello deberá notificar a las partes con suficiente antelación para

${ }^{11}$ Respecto a este tema, véase, Poudret y Besson (n. 9), pp. 83-119; Fouchard, Gaillard, Goldman (n. 10), pp. 78-93; Redfern y Hunter (n. 9), pp. 283-292.

${ }^{12} \mathrm{Tal}$ calificación fue confirmada por sentencia pronunciada por la CA de Paris, con fecha 28 de octubre de 1997, en el asunto "Soc. Procédés de fabrication pour le béton c. Libye”, Rev. Arb., 1998.

${ }^{13}$ Sobre la base de ello se les ha denominado como una "ficción jurídica", véase KAUFMANn-Kohler, "Le lieu de l'arbitrage à l'aube de la mondialisation”, in Rev. Arb., 517, 1998, p. 536 .

${ }^{14}$ Véase Miguel Gómez Jene, El arbitraje internacional en la Ley de Arbitraje de 2003, Madrid, Colex, 2007, pp. 11-112. Bajo el mismo postulado, Miguel Virgós Soriano, “Arbitraje comercial internacional y Convenio de Nueva York de 1958”, en diario La Ley, año XXVII, $\mathrm{N}^{\circ}$ 6679, 2007. Por lo demás, tal libertad debe matizarse en relación con el RAU, que restringe algunas de estas actuaciones (véase art. 16).

${ }^{15}$ Se trata de una regla recogida en todos los derechos comparados, salvo en el Derecho italiano en el que la cuestión es controvertida. La jurisprudencia francesa ha enunciado que los árbitros pueden decidir ellos mismos, sin el acuerdo de las partes. Véase Corte de Casación, $2^{\circ}$ Civil, del 9 de abril de 1994 (no publicada), que señala al efecto: "que la convención de arbitraje no preveía que todo el procedimiento arbitral debía desarrollarse obligatoriamente en Lyon, sino solamente que en ese lugar debía llevarse a cabo al menos el pronunciamiento del laudo, que en sí mismo conlleva múltiples consecuencias relacionadas al ejercicio de los recursos”. Sentencia citada por Clay (n. 9), p. 203. 
permitir su asistencia a tales inspecciones (art. $16.2^{\circ}$ ). Lo que no es opcional es el lugar donde el laudo debe dictarse, en tanto debe corresponder siempre al lugar del arbitraje (art. 16.3 $\left.{ }^{\circ}\right)^{16}$.

Es preciso considerar que, si bien se acostumbra a decir que la sede de arbitraje corresponde a un Estado, lo cierto es que no tiene por qué coincidir con él, sino, más bien, con una determinada plaza o ciudad -por ejemplo, Ginebra, Lima, Madrid, Miami, Montevideo o París-. Lo que ocurre es que por lo general la legislación que rige al lugar será la del país del que forme parte dicho sitio, así como los tribunales que apoyen y controlen esta labor serán los propios de dicho Estado.

La importancia de esta elección reside en su efecto trascendente sobre el juicio arbitral. En efecto, si bien el arbitraje es una institución autónoma que nace y toma fuerza de la mano de la voluntad de las partes, también es cierto que esta justicia posee varias limitaciones en que sencillamente no puede actuar; en estos casos se debe producir una necesaria interacción con tribunales que sí poseen tales facultades, como los estatales, con el objetivo de completar ciertas labores en dos campos concretos: apoyo y control. Dado que para el arbitraje comercial internacional no existen tribunales supranacionales, éstos deberán buscarse en relación con un Estado determinado, la elección de las partes a estos efectos, tenderá a buscar una red de apoyo que tienda a dar eficacia al arbitraje y seguridad a las partes; si la decisión no se efectúa o no goza de claridad, el aquél podría quedar desprotegido y, en definitiva, entorpecer la marcha del mismo ${ }^{17}$.

${ }^{16}$ Abundan los numerosos reglamentos que permiten al tribunal arbitral celebrar reuniones en un lugar distinto del lugar del arbitraje con ciertas reservas, por ejemplo, art. 14 del reglamento de la CCI, que distingue entre el lugar de las deliberaciones del tribunal, que no están sometido a ninguna restricción y las audiencias y reuniones que pueden celebrarse en lugar distinto a la sede del arbitraje "previa consulta de las partes". Estas previsiones son seguidas por la generalidad de los reglamentos arbitrales de América Latina. Frente a ello, es preciso advertir que puede resultar peligroso en determinados supuestos otorgar al tribunal arbitral un derecho ilimitado de acordar la celebración de reuniones en cualquier lugar, toda vez que la sede tiene consecuencias no sólo durante el procedimiento sino, también, en la fase posarbitral, de manera que la celebración de reuniones, siquiera sea con carácter fortuito, puede suponer que el arbitraje se vincule a un ordenamiento que las partes no previeron. En tal sentido, véase caso Hiscox $v$. Outhwaite suscitado entre la Queen's Bench Division inglesa en 1991.

${ }^{17}$ Así, el art. 20 de la LMU, señala: "Lugar del arbitraje: Las partes podrán determinar libremente el lugar del arbitraje. En caso de no haber acuerdo al respecto, el tribunal arbitral determinará el lugar del arbitraje, atendidas las circunstancias del caso, inclusive las conveniencias de las partes. 2. Sin perjuicio de lo dispuesto en el párrafo precedente, el tribunal arbitral podrá, salvo acuerdo en contrario de las partes, reunirse en cualquier lugar que estime apropiado para celebrar deliberaciones entre sus miembros, para oír a los testigos, a los peritos o a las partes, o para examinar mercancías u otros bienes o documentos". 
Debido a lo anterior, se entiende que la selección de la sede del arbitraje en un contrato comercial internacional es vital tanto desde el punto de vista jurídico como práctico ${ }^{18}$, en tanto se considerará como el lugar formal en que es llevado, es decir, el lugar en que se sustancia normalmente. La ley de la sede, conocida como lex loci arbitri o lex arbitrii ${ }^{19}$, será el vínculo que servirá para determinar el sistema de referencia que proporcionará el marco jurídico particular que se aplicará al arbitraje y las autoridades judiciales con capacidad de intervención sobre el mismo ${ }^{20}$, sea en su faceta positiva (asistir a los árbitros como jueces de apoyo) ${ }^{21}$, o negativa (control de laudos ${ }^{22}$. Más aún, el papel central de la sede se puede vislumbrar en el alcance de las decisiones judiciales ${ }^{23}$, principalmente la de nulidad del laudo, pues aquélla tendrá -en principio-, efectos amplios en relación con cualquier otro sistema jurídico ${ }^{24}$.

${ }^{18}$ Para mayor amplitud en este tema, véase Redfern \& Hunter (n. 9), pp. 270-277; Fouchard et al. (n. 9), párrafos 1238-1240; William PARK, "The Lex Loci Arbitri and International Commercial Arbitration”, in Review International and Comparative Law Quarterly, No 32, 1983, pp. 21-52; William PARK, "Arbitration of International Business Disputes: Studies”, in Law and Practice, 1983, Oxford University Press, 2006.

${ }^{19}$ Formada tanto por las reglas establecidas en los códigos procesales o leyes especiales sobre el arbitraje, como por las leyes de fondo y de las convenciones y tratados internacionales incorporados al derecho del país en cuestión.

${ }^{20}$ Por ello se dice que esa elección conlleva el sometimiento al derecho de ese país, incluidas sus disposiciones obligatorias de la ley interna en materia de arbitraje. No es sólo un marco procesal. Véase REDFERN et al. (n. 9), pp. 154-171.

${ }^{21}$ A modo de ejemplo, la CCI emplea una serie de criterios de selección de la sede con el objetivo de garantizar el favor arbitratis. Entre ellos, toma en consideración la neutralidad del Estado, que este Estado se haya adherido a los convenios internacionales más relevantes (por ejemplo, CNY), analiza el estado de su legislación y la adopción de los principios básicos del arbitraje internacional, y observa también la actitud de los tribunales estatales frente a esta materia en cuanto reconozcan cada uno de los principios señalados (competenciacompetencia, de nulidad del laudo, de intervención mínima). Sobre el particular véase E. Silva Romero, "Breves observaciones sobre la modernidad del arbitraje internacional. A propósito de la nueva ley española de arbitraje", en Tribuna Abierta, No 9, 2004, pp. 12-14; FERnÁndez Rozas (n. 9), p. 43.

${ }^{22}$ Virgós Soriano (n. 14) expresa que, si bien a este modelo se le ha criticado la nacionalización del arbitraje internacional, en la medida que fuerza su localización, esta solución proporciona seguridad jurídica, pues las partes saben desde el comienzo a qué atenerse tanto en términos de tribunales como de marco jurídico de referencia.

${ }^{23}$ Conforme al CNY 1958 un laudo vinculante pronunciado en un Estado contratante debe ser reconocido y ejecutado en los demás Estados contratantes, salvo que haya sido anulado o sus efectos suspendidos en el Estado de origen. Esto significa, positivamente, que emitido de forma válida tendrá vigencia en los demás Estados contratantes y, negativamente, que si es anulado o suspendido, no lo hará.

${ }^{24} \mathrm{M}^{\mathrm{a}} \mathrm{V}$. Cuartero Rubio, El recurso de anulación contra el laudo arbitral en el arbitraje comercial internacional, Madrid, Ed. Eurolex, 1997, p. 26 y ss.; Fernando CANTUARIAS SALAVERRY, "Cuestiones generales aplicables a las causales de anulación de laudos arbitrales 
¿Qué ocurre si las partes tramitan un determinado juicio arbitral en una sede A, y luego el árbitro dicta el laudo en una sede B?, ¿̇cuál se entiende como sede arbitral?, ¿es posible sostener que un arbitraje posee dos sedes? Si bien podríamos pensar que esta situación es posible sobre la base de la autonomía de la voluntad que inspira a la institución arbitral, lo cierto es que lo anterior no puede afirmarse con facilidad. Para ello, deben considerarse dos elementos que explican la incongruencia que puede producirse:

1. El papel que deben cumplir los tribunales estatales $y$

2. La legislación aplicable.

El papel de los tribunales estatales no es indivisible, si bien existen labores diferentes en cuanto apoyo y control que deben prestar a los tribunales arbitrales, todo su actuar se encuentra conectado, prueba de ello es que entre las causales para anular el laudo, normalmente existe alguna que liga con la correcta marcha del procedimiento. La segunda se desprende de la idea precedente, en tanto la lex arbitrii es una unidad que plantea unos determinados postulados y principios, de manera que no pueden aplicarse sus normas de forma independiente y aislada al procedimiento y otras en la sentencia, ello podría causar que el juez de control de un Estado aplique unas normas que el juez de apoyo de otro no contempló en su momento, provocando la nulidad y pérdida de eficacia del arbitraje.

Si en la práctica tal situación se produce, se crea normalmente una ficción jurídica en que la sede corresponderá al lugar en que se dicta el laudo ${ }^{25}$; el árbitro debe asumir esta situación, considerando la legislación pertinente tanto en el procedimiento como en su respectivo fallo, a fin de evitar que el arbitraje se torne ineficaz.

\section{Elección de sede arbitral}

La elección de la sede es una decisión que pertenece a las partes del conflicto, con alguna excepción ${ }^{26}$, en virtud de su autonomía de la voluntad,

dictados en el foro y a las causales para no reconocer y ejecutar laudos arbitrales dictados en el extranjero", Themis, Revista de Derecho, No 50, 2005, pp. 87-95.

${ }^{25}$ En general se suele dar preferencia al lugar del pronunciamiento de laudo, aunque no existe un total consenso en dicha idea. Cantuarias Salaverry (n. 24), p. 88 y ss.

${ }^{26}$ Esta elección puede estar limitada en algunas ocasiones de carácter obligatorio e inderogables por las partes, como ocurre con el art. 22 del convenio de las Naciones Unidas sobre el Transporte Marítimo de Mercancías (Reglas de Hamburgo), que establece: "El procedimiento arbitral se incoará, a elección del demandante, en uno de los siguientes lugares: a) Un lugar situado en un Estado en cuyo territorio se encuentre: (i) El establecimiento principal o, a falta de éste, la residencia habitual del demandado; o (ii) El lugar de celebración del contrato, siempre que el demandado tenga en él un establecimiento, sucursal o agencia por medio de los cuales se haya celebrado el contrato; o (iii) El puerto de carga o el puerto de descarga; o b) Cualquier lugar designado al efecto en la cláusula compromisoria o el compromiso de arbitraje". 
sin que pueda incidir en aquélla ninguna condición adicional (como la nacionalidad de las partes o del litigo con el Estado escogido ${ }^{27}$. Además de la lex arbitri, las partes, por regla general, valorarán otros factores al tomar la decisión correspondiente, como la aplicación e interpretación que los tribunales estatales tengan sobre la ley arbitral y la institución del arbitraje; factores económicos y otras ventajas, así como limitaciones contempladas por el país en cuestión. Cada lugar plantea una realidad por completo diferente entre sí, de modo que al elegir se estará optando por un cierto esquema jurídico ya asentado en dicho sitio.

Si las partes nada señalan sobre el particular, será al tribunal arbitral ${ }^{28}$ a quien le corresponderá efectuar tal elección, o a la institución arbitral pertinente si las partes han optado por este tipo de $\operatorname{arbitraje}^{29}$, en ambos casos, debieran tomarse en consideración la opinión de las partes y las circunstancias del caso a dirimir ${ }^{30}$, incluyendo las consecuencias legales y prácticas derivadas de esta decisión. La primera consideración conduce a elementos de carácter pragmático tales como la proximidad de las partes y del tribunal al lugar elegido, la necesidad de practicar en él pruebas sustanciales como inspecciones oculares o pruebas testificales; la conveniencia de abaratar los costos y de evitar desplazamientos innecesarios de los miembros del tribunal, de los abogados de las partes y de los testigos juega como elemento determinante en múltiples ocasiones; a lo que cabe añadir la garantía de la efectividad posterior del resultado del procedimiento arbitral. Por su parte, la expresión "conveniencia de las partes", tiene una mayor dificultad interpretativa, prueba de ello es que su inclusión no fue

${ }^{27}$ Véase Verdera y Tuells (n. 9), pp. 89-102; H. Verbist, "Le lieu de l'arbitrage dans le processus de nègotiation et de rédaction d'une clause d'arbitrge", in Revue du Droit Comparé, 1993, p. 220 y ss.

${ }^{28}$ Así, por ejemplo, lo disponen las leyes de México y Colombia, la determinación del lugar de arbitraje, a falta de elección por las partes, será efectuada por el tribunal arbitral (Código de Comercio, art. 1436; decreto 1818; art. 132, respectivamente).

${ }^{29}$ Ejemplo de este último cauce es el arbitraje administrado por la CCI en el que la "sede del arbitraje será fijada por la Corte a menos que las partes la hayan convenido" (art. 14 . $1^{\circ}$ reglamento del CCI). Otros reglamentos establecen una suerte de "sede interina" hasta que exista un pronunciamiento definitivo por parte del tribunal arbitral una vez constituido; así, el art. $13.1^{\circ}$ Reglamento de la AAA declara que si las partes no se ponen de acuerdo con respecto al lugar del arbitraje, la propia AAA podrá inicialmente determinar el lugar del arbitraje, sujeto a la facultad del tribunal de determinar finalmente el sitio dentro de los sesenta días después de su constitución. Dichas determinaciones se harán tomando en cuenta los argumentos de las partes y las circunstancias del arbitraje. Por último, un tercer bloque de reglas fija, en ausencia de designación expresa, la sede de la propia institución arbitral (por ejemplo, reglamento del Centro de Mediación y Arbitraje Comercial de la Cámara Argentina de Comercio; reglamento del Centro de Conciliación y Arbitraje de Panamá). Sobre el tema, véase Fernández Rozas (n. 9), p. 27.

${ }^{30}$ Véase art. 20 de la LMU. 
pacífica en los trabajos preparatorios de la LMU, sobre la base de los distintos significados que podrían sostenerse, desde el lugar que resulte más neutral para las partes, pasando por la sede donde existe una normativa más favorable, hasta el lugar donde existan mayores facilidades de acceso de todos los participantes en el procedimiento ${ }^{31}$.

Si las partes omiten realizar toda selección, no existe institución designada para hacerlo y el tribunal arbitral no goza de estas facultades, serán los tribunales estatales de los países en que se solicita los que deberán efectuar la aludida elección.

Lo recomendable es que las partes efectúen la elección de la manera más clara posible en el respectivo acuerdo. La manera de establecer la sede del arbitraje es, simplemente, agregar una oración a la cláusula arbitral, como sigue: "La sede del arbitraje será la: (ciudad/Estado/país)". Una variación de esta sencilla fórmula puede ser utilizada cuando las partes deseen incluir en el contrato un disuasivo para la iniciación del arbitraje. Así, por ejemplo, si una de las partes fuera mexicana y la otra fuera francesa, la cláusula puede establecer:

"La sede del arbitraje será París, Francia, si el arbitraje es iniciado por la parte mexicana, y la sede del arbitraje será la Ciudad de México, D.F., México, si el arbitraje es iniciado por la parte francesa”.

Con todo, estas cláusulas no son aconsejables, ya que una cláusula desequilibrada de este tipo puede crear un incentivo para que una parte incumpla o continúe con su conducta violatoria del contrato, con la expectativa de que la otra parte no querrá iniciar el arbitraje en el foro de la parte que ha incumplido.

Para dimensionar la trascendencia de la elección debemos considerar, a priori, que el juez de la sede podrá aplicar, en ciertos casos, su propio derecho en la determinación del alcance de las intervenciones posibles respecto de un arbitraje, lo que atañe a cuestiones tales como el acuerdo de arbitraje, la constitución y la competencia del tribunal arbitral, la sustanciación de las actuaciones, el contenido del laudo, las causales de nulidad del mismo y todo lo relativo a la intervención y a la asistencia de los jueces en el procedimiento; asimismo, el lugar del arbitraje determina el Estado en que se considera que el laudo ha sido dictado, lo que interesa al solicitar su reconocimiento o la ejecución del laudo extranjero. Dicha

${ }^{31}$ Esta delimitación se observa también en relación con el arbitraje marítimo, donde la elección de la sede se vincula a la sede de las instituciones de arbitraje especialmente aptas para resolver la controversia, por ejemplo, la LMAA; la CAMP, o la SMA. Sobre el tema, véase Fernández Rozas (n. 9), pp. 28-30. 
determinación tiene como consecuencia, además, la calificación de si un arbitraje es nacional o internacional y la arbitrabilidad de una materia.

\section{RELEVANCIA DE LAS SEDES ARBITRALES: PERSPECTIVAS A CONSIDERAR}

\section{Desentrañando el dilema: entre la localización y la deslocalización}

La importancia de la sede en el arbitraje comercial internacional no es un tema que genere un fácil consenso, es más, existen al menos dos líneas sobre esta materia opuestas entre sí, la primera ha ido instaurando lentamente la tesis de la pérdida de significancia del mismo, basándose de manera primordial en:

1. La CNY (art. vi) y la LMU (art. $36 \mathrm{~N}^{\circ} 1$ ), que permiten la ejecución de la sentencia arbitral a pesar de la petición de nulidad de la misma en el Estado sede ${ }^{32}$; a ello se agrega que varios países se han fundado en el art. VII de la CNY para hacer prevalecer su derecho interno sobre el texto internacional a fin de ejecutar laudos anulados por los tribunales del lugar de la sede arbitral ${ }^{33}$; el hecho de que las

${ }^{32}$ La convención afirma que si se ha pedido a la jurisdicción de la sede del arbitraje la anulación o la suspensión de la sentencia, la autoridad judicial ante la cual se invoca "podrá", si lo considera procedente, aplazar la decisión sobre la ejecución de aquélla. A este respecto, cabe señalar que el proyecto inicial de la CNY, preparado por la CCI, si hacía referencia a laudo internacional y no extranjero, de manera que los redactores propugnaban por un arbitraje verdaderamente internacional y deslocalizado, sin un nexo particular con un ordenamiento jurídico nacional. Fue con posterioridad, y ante la reticencia de ciertos países influenciados por la lex arbitri y la sede arbitral, que los redactores optaron por la versión que hoy impera; no obstante ello y la referencia al lugar del arbitraje, el texto mismo de la CNY permite reconocer el carácter visionario de sus redactores. sobre el tema, véase entre otros: convención sobre Reconocimiento y la Ejecución de Sentencias Arbitrales Extranjeras, CNY (1958). Recuperado el 10 de noviembre de 2009, de la CNUDMI http: www.uncitral.org/uncitral_texts/arbitration/ nyconvention.html; Fernando Mantilla-Serrano, "Algunos apuntes sobre la ejecución de los laudos anulados y la Convención de Nueva York", 15 International Law, Revista Colombiana de Derecho Internacional, 2009, pp. 15-40; Péreznieto \& Graham (n. 9), pp. 197-208; Albert Jan van den BerG, "La aplicación de la Convención de Nueva York de 1958 a laudos no nacionales", en G. TAWIL \& E. Zuleta (coords.), El Arbitraje comercial internacional. Estudio de la Convención de Nueva York con motivo de su $50^{\circ}$ Aniversario, Buenos Aires, Ed. Abeledo-Perrot, 2008, p. 100 y ss.

${ }^{33}$ Esta disposición señala: "Las disposiciones de la presente Convención no afectarán la validez de los acuerdos multilaterales o bilaterales relativos al reconocimiento y la ejecución de las sentencias arbitrarles concertados por los Estados contratantes ni privarán a ninguna de las partes interesadas de cualquier derecho que pudiera tener a hacer valer una sentencia arbitral en la forma y medida admitida por la legislación o los tratados del país donde dicha sentencia se invoque". 
causales para rechazar la ejecución de un laudo sean normalmente las mismas que las establecidas para anular una sentencia arbitral, de manera que no se justificaría un doble control $^{34} \mathrm{y}$

2. La pérdida de relevancia del recurso de nulidad que, incluso, es posible renunciar con anticipación en ciertas legislaciones.

La segunda tesis dubita y desconoce parte de lo antes expresado y afirma, en cambio, que dicha elección entraña efectos relevantes asociados principalmente a la validez del laudo arbitral y con ello la viabilidad del laudo en el contexto internacional.

Se trata de un tema controvertido y muy relevante en la actualidad, detrás de él subyacen dos concepciones filosóficas del instituto arbitral bien diferenciadas:

- la primera tiene un sello universalista, donde la sede no es más que un parámetro en medio de muchos otros ${ }^{35}$;

- la segunda presenta un corte territorialista y considera que la sede es un elemento esencial en el arbitraje $\mathrm{e}^{36}$.

En relación con ello, cabe recordar que una de las primeras filosofías del arbitraje fue propuesta por Henri Batiffol ${ }^{37}$, en aquella época el paradigma reinante era que los árbitros debían aplicar las normas de conflictos de la sede del arbitraje "en tanto lex for ${ }^{\text {" } 38}$. Fue Berthold Goldman el que propuso la idea según la cual los árbitros no tenían foro, y de existir uno, sería el mundo ${ }^{39}$. Asimismo, fue Francescakis (1960) el que señaló que una disciplina tan técnica como el DIPr podía enriquecerse en cuestiones tales como la calificación o el orden público internacional, adoptando conceptos

${ }^{34}$ Véanse arts. 34 y 36 de la LMU.

${ }^{35}$ Para Thomas Clay, esta disyuntiva encuentra su base en el diferente origen cultural e intelectual de sus autores, pero de forma opuesta a aquéllos que se observa comúnmente, no se trata de divergencias entre diferentes nacionalidades o entre sistemas jurídicos diversos como sería el Common law y Civil law, sino de divergencias más sutiles. Clay (n. 9), pp. 193-194.

${ }^{36}$ Sobre el tema, en extenso véase Emmanuel Galllard, Teoría jurídica del arbitraje internacional, Asunción, Thomson Reuters, 2010. Plantea al respecto tres representaciones: la primera concibe al arbitraje como un componente de un determinado sistema jurídico, el de la sede arbitral. La segunda que denomina "westfaliana" comparte con la anterior su anclaje positivista, pero es más cosmopolita o internacional, ya que supone que todos los ordenamientos que de alguna manera se vinculen con un arbitraje pueden legítimamente pronunciarse acerca de la validez del laudo arbitral. La última plantea la existencia de un orden jurídico arbitral transnacional, donde ningún Estado sería referencia esencial desde el momento en que los árbitros no imparten justicia a nombre de ellos sino "al servicio de la comunidad internacional".

${ }^{37}$ Henri Batiffol, Aspects philosophiques du droit international privé, Paris, Dalloz, 1956.

${ }^{38}$ En 1957 el Instituto de Derecho Internacional adoptó la resolución de Ámsterdam, basándose en el informe de G. Sauser-Hall. Gaillard (n. 36), p. 7.

${ }^{39}$ Berthold Goldman, "Les conflits de loi dans l’arbitrage internacional de droit privé", dans Recueil des tours, vol. 109, 1963, p. 347 ss. 
universalistas, que estimaba emanados del Derecho natural ${ }^{40}$. Veremos a continuación ambos escenarios.

\section{A. La exaltación de la autonomía como base de la deslocalización ${ }^{41}$}

Es justo partir señalando que esta concepción no parece haber generado una gran cantidad de adeptos y ciertamente ha sido en los círculos franceses donde más se ha asentado; no obstante, consideramos que esta vertiente ha generado debates muy interesantes en relación con el arbitraje, que no ha quedado en el sólo plano de las ideas sino que ha logrado plasmarse en ciertas sentencias judiciales como veremos más adelante, por lo que se puede afirmar que la importancia del lugar se ha relativizado ${ }^{42}$. La tesis en cuestión desvincula el arbitraje del Estado sede, éste último no tendría más importancia que cualquier otro Estado cuyas legislaciones pudieran ser aplicables. Se aboga así por el carácter transnacional que impregna al instituto arbitral, cuyas manifestaciones ya habían sido anunciadas hace tiempo ${ }^{43}$.

Esta corriente presenta una defensa acérrima del principio de la autonomía como parte sustancial del instituto arbitral ${ }^{44}$, en orden a constituir al arbitraje internacional completamente desterritorializado (arbitration unbound), en ella encontramos cuatro argumentos independientes entre sí que tienden a dar respaldo a esta tesis. El primero se relaciona con la pérdida de relevancia del sistema conflictualista clásico en el Derecho Arbitral, que habría cedido hacia la primacía de la regla material ${ }^{45}$, de manera de fijar

${ }^{40}$ Véase Gaillard (n. 35), p. 8.

${ }^{41}$ Incluso, se alude a la multilocalización, es decir, la sujeción del laudo a la ley del país en el cual es invocado por diferentes razones que provocan en muchos casos situaciones complejas al no existir unicidad de criterios sobre diversos elementos. Véase P. Mayer, "L'insertion de la sentence dans l'ordre juridique français", dans Le droit et la practique de l'arbitrage International en France, Deduci, 1984, pp. 81-84.

${ }^{42}$ En esta línea, Mantilla-Serrano (n. 32), p. 19.

${ }^{43}$ Pierre Lavive, “Ordre public transnacional (ou réellement internacional) et arbitrage internacional”, in Rev. Arb., 1986, pp. 326-371.

${ }^{44}$ Para un completo análisis de la injerencia del principio de autonomía en el instituto arbitral, véase M. Petsche, The growing Autonomy of International Commercial Arbitration, München, European Law Publishers, 2005, pp. 3-4; José Carlos Fernández Rozas, "El arbitraje comercial internacional entre la autonomía, la anacionalidad y la deslocalización", en Revista Española de Derecho Internacional, vol. LVII, 2005, pp. 605-636. Cuestionando seriamente la factibilidad de este principio, a lo menos en parte, en el arbitraje comercial internacional, véase C. Chatterjeek, "The Reality of the Party Autonomy Rule in International Arbitration", in Journal of International Arbitration, vol. 20, N ${ }^{\circ}$, December 2003, pp. 539-560.

${ }^{45}$ No obstante, esta apreciación no es unívoca. La realidad demuestra que el recurso al Derecho nacional goza aún de ciertos defensores, especialmente en los sistemas del Common 
el resultado sin preocuparse del juego e interacción de reglas de conflicto y puntos de contacto ${ }^{46}$. El Derecho Arbitral se desliga así de la Escuela del Derecho Internacional Privado, pregonando su completa autonomía en la materia ${ }^{47}$.

La segunda -ligada a la anterior- pone acento en la irrelevancia de la sede en relación con las leyes aplicables. En esta línea se señala que el Estado sede no crea lazos sustanciales con la controversia, sino, más bien, se trata de un elemento artificial y sin importancia en relación con varias materias como son: la ley aplicable al fondo del litigio, ley aplicable al procedimiento, al lugar donde se desarrollan las audiencias y donde se ejecuta el laudo arbitral. Esto ocurriría porque en materia internacional, a diferencia de un arbitraje interno, un árbitro puede tener varios puntos de contacto con legislaciones de más de un país, lo que le lleva en la búsqueda de la ley aplicable a cada caso, las que no necesariamente se vinculan con el Estado sede ${ }^{48}$. Una muestra de ello se da en la evolución de la determinación del Derecho aplicable: de la aplicación de la norma de conflicto de la sede, se pasa a la norma de conflicto "más apropiada" o la norma de conflicto del país más estrechamente vinculado con el arbitraje, para desembocar en algunos textos a las "reglas que los árbitros consideren más oportunas". De hecho, hoy existe libertad para que las partes escojan la legislación o reglas que estimen convenientes para el procedimiento y el fondo del litigio, y éstas últimas podrían estar desvinculadas a toda ley nacional, como ocurre con la lex mercatoria ${ }^{49}$, de manera que el Estado sede ninguna injerencia tendría sobre el particular ${ }^{50}$. Por otro lado, hoy las partes

Law. De hecho, ya en la CNY se alude a una ley aplicable en materia de capacidad, lo que permite afirmar que este texto internacional ampara la sujeción de la capacidad en materia de arbitraje internacional a un derecho nacional e, indirectamente, confirma el recurso al sistema conflictualista. La interpretación de norma no es pacífica. Véase Fouchard, Gaillard and Goldman (n. 9), p. 242.

${ }^{46}$ Por ello Mantilla Serrano (n. 9), p. 239, se pregunta si es el triunfo del fin sobre el método, o el de la real intención de las partes y del respeto de sus expectativas, sobre construcciones artificiales, locales o coyunturales.

${ }^{47}$ Los partidarios de otorgar un papel más importante a la sede son aquéllos que provienen de la escuela del Derecho Internacional Privado, mientras que aquéllos que pretenden reducir esta importancia llegaron al arbitraje sin pasar por esta Escuela, lo que se justifica en el hecho de que para la primera vertiente el tema de los "conflictos de leyes o de jurisdicción" es crucial, para los segundos, en cambio, el arbitraje implica la negación de este tipo de conflictos, es el derecho de las reglas materiales que sobrepasan estos conflictos a partir del Derecho transnacional.

${ }^{48}$ Sobre la defensa del arbitraje transnacional, véase Bruno Oppetiт, Teoría del arbitraje, Bogotá, Legis, 2006, pp. 192-195.

${ }^{49}$ Véase art. 28 de la LMU.

${ }^{50}$ Esta desvinculación del contrato y del arbitraje puede ser progresiva, las partes pueden elegir reglas que no tengan un origen estatal para gobernar sus relaciones, por ejemplo, la 
se hallan en completa libertad para determinar el procedimiento arbitral ${ }^{51}$ o las normas por las que se regirá.

Asimismo, se ha señalado que el Derecho Procesal del lugar del arbitraje carece de vocación para regularlo con alguna excepción ${ }^{52}$. Lo mismo ocurre con el juez de apoyo, pues también ha perdido injerencia al no ser ya preciso contar con una sede para acudir a un tribunal estatal ${ }^{53}$, en tal sentido, existen legislaciones que contemplan la posibilidad de prestar asistencia aun en aquellos casos en que no se hubiere determinado el lugar del arbitraje ${ }^{54}$.

En tercer lugar, se argumenta que, si bien antes un laudo anulado por un Estado sede impedía su ejecución por otro Estado, actualmente tal afirmación ha perdido efectividad. Ello se ha apreciado en determinados casos jurisprudenciales en los que, pese a la anulación de su laudo por el Estado sede, éstos fueron reconocidos con posterioridad y ejecutados en

lex mercatoria, o la aplicación de los principios generales del Derecho, o comunes (pacta sunt servanda, fuerza mayor, rebuc sic stantibus, el principio rector de la buena fe en las relaciones comerciales, respeto a los derechos adquiridos, el de equidad, etcétera).

${ }^{51}$ En esta línea resulta de interés analizar la evolución del reglamento de la CCI, toda vez que en su versión de 1955 establecía que en ausencia de pacto al respecto, el Derecho aplicable al procedimiento sería el del país sede del arbitraje, pero luego esta referencia fue eliminada con la modificación al Reglamento efectuada en 1975. Actualmente, en su 90 art. 15.1 consagra de manera expresa la libertad que tiene el tribunal arbitral, a falta de acuerdo de las partes, para determinar las normas aplicables al procedimiento "ya sea con referencia o no a un derecho nacional aplicable al arbitraje".

${ }^{52}$ Véase leyes de Colombia (arts. 153 y 155 del D.L. 1818/98); Costa Rica (art. 29 del D.L. 7727/97) y de Ecuador (art. 37 de la LA 1997).

${ }^{53}$ Así, la Corte de Casación francesa, en un fallo del 1 de febrero de 2005, aceptó que las cortes francesas eran competentes como jueces de apoyo para la constitución de un tribunal arbitral, en un procedimiento de la CCI donde las partes no habían pactado la sede y, por lo tanto, en principio no existía competencia del juez francés. El único punto de contacto con Francia radicaba en que el convenio arbitral entre el Estado de Israel y la NIOC establecía que, en caso de desacuerdo entre los coárbitros respecto del nombramiento del tercer árbitro, el presidente de la CCI (con sede en París) sería la autoridad de nominación. Ante la renuencia del Estado de Israel a designar un coárbitro, la NIOC recurrió a la jurisdicción francesa para el nombramiento judicial de un árbitro. La Corte señaló que los tribunales franceses no podían negarse a efectuar esta función de apoyo a la constitución del tribunal so pena de incurrir en denegación de justicia, vulnerando el orden público internacional. De este modo, reconoce la existencia de un convenio arbitral, sin necesidad de preocuparse por las normas procesales aplicables al mismo y sin importar el lugar del proceso (o la falta de éste) para que el juez francés preste su apoyo. Corte de Casación, sección Primera Civil, 1 de febrero de 2005.

${ }^{54}$ Véase art. 8.1 de la ley española de arbitraje 60/2003, que establece: "Para el nombramiento judicial de árbitros será competente el Juzgado de Primera Instancia del lugar del arbitraje; de no estar éste aún determinado, el del domicilio o residencia habitual de cualquiera de los demandados; si ninguno de ellos tuviere domicilio o residencia habitual en España, el del domicilio o residencia habitual del actor, y si éste tampoco los tuviere en España, el de su elección". 
un Estado diverso. Así ocurrió a principios de la década de 1980 en el caso Societé Palback Ticaret c. Société Norsolor ${ }^{55}$ en que el laudo, proferido en Austria, fue parcialmente anulado por la Corte de Apelación de Viena, sobre la base de que los árbitros decidieron aplicar la lex mercatoria lo cual -según la Corte vienesa- equivalía a fallar en equidad (amiable composition) cuando el tribunal no estaba facultado para ello ${ }^{56}$. La Corte de Casación francesa reconoció la validez del laudo proferido en Austria, y anulado, a su vez, por las cortes austriacas, y sostuvo que, con base en el art. VII de la CNY, un juez no puede apoyarse en esa convención para denegar el reconocimiento y ejecución de un laudo cuando su Derecho nacional permita considerarlo como válido y susceptible de ejecución. En opinión de la Corte corresponde al juez francés de la ejecución

“...investigar, inclusive de oficio, si el derecho francés no permite a la parte que se ve beneficiada por el laudo, el derecho a prevalerse del mismo".

Otra decisión proferida igualmente por la $1^{\text {a }}$ Sala de la Corte de Casación de París, en la causa Société Polish Ocean Line v. Société Jolasry ${ }^{57}$, consideró que la suspensión o anulación del laudo en su país de origen, si bien constituye una de las causales previstas por la CNY, para poder denegar su reconocimiento y ejecución, también lo es que esta causal no se encuentra dentro de la lista de motivos contemplados en el art. 1502 del NCPC francés, que permiten negar e reconocimiento de laudos extranjeros y, por lo tanto, en aplicación del art. VII de la CNY, la suspensión o anulación del laudo por un tribunal del país donde fue dictado no justifica en sí misma la denegación del reconocimiento y ejecución del mismo en Francia. Así, esta Corte señaló:

“(...)El juez francés no puede denegar la ejecución, cuando el laudo ha sido anulado o suspendido por una autoridad competente del país en el cual ha sido rendido, con base en una causal que no forma parte de las enumeradas en el Art. 1502 NCPC, aún cuando esté prevista por el Art. V, 1, e de la CNY (...)" ${ }^{58}$.

${ }^{55}$ Corte de Casación de París, sección $1^{\text {a }}$ Civil, 9 de octubre de 1984. Se puede revisar en Journal of International Arbitration, 2, 67, XI, YBCA, 484, 1986, 24 International Legal materials, ILM, 360, 1985; Revue d'Arbitrage, 1983, p. 525; Collection of ICC Arbitral Award 1974-1985, Kluwer, p. 122. 67.

${ }^{56}$ Corte de Casación de París (9 de octubre de 1984, 2 Journal of International Arbitration,

${ }^{57}$ Corte de Casación, sección Primera Civil, 10 de marzo de 1983, in Revue de l'Arbitrage, 255, 1993.

${ }^{58}$ Véase Mantilla Serrano (n. 9), pp. 230-232. 
Se inscribe en esta línea, aunque con claros tintes diferenciadores en cuanto a los fundamentos esgrimidos, el caso Hilmarton c. OTV ${ }^{59}$. En éste, la Corte de Casación francesa reconoció la validez de un laudo proferido en Ginebra en el cual el árbitro único había juzgado que el contrato en cuestión -regido por el Derecho suizo- violaba el Derecho argelino, que prohíbe todo tráfico de influencias y sobornos, y atentaba contra el orden público internacional. La Corte ginebrina y el Tribunal Federal suizo anularon el laudo arbitral, pues consideraron que la violación de la ley argelina chocaba con las buenas costumbres establecidas en el Derecho suizo, de modo que la decisión del árbitro, de anular el contrato, constituía una violación evidente del Derecho suizo. La Corte francesa volvió sobre el art. 1502 del $C P C$ el cual no contempla como motivo para denegar el reconocimiento del laudo el hecho de que éste se haya anulado en el país de origen, pero fue un poco más allá al declarar expresamente que el laudo dictado en Suiza es uno internacional que no se encuentra integrado al sistema jurídico de ese Estado, de manera que su existencia permanece establecida pese a su anulación y su reconocimiento en Francia no es contrario al orden público internacional. Asimismo, encontramos la sentencia de la Corte de Apelaciones de París de 2005 en el caso Bechtel ${ }^{60}$. Aquí, la Corte sostuvo que la exigencia reinvindicada por la DAC, parte perdedora en el arbitraje y que había conseguido la anulación del laudo por la Corte de Dubai, bajo el argumento de que habían sido escuchados ciertos testigos sin que éstos hubiesen prestado juramento) de agotar todos los recursos legales en el país de origen (del laudo) antes de otorgarle reconocimiento y ejecución en Francia, es incompatible con los principios fundamentales del arbitraje en Francia, apoyándose en el artículo 1498 y siguientes del NCPC. Afirma, además, que las decisiones judiciales proferidas como resultado de un procedimiento de anulación de laudo, al igual que aquéllas relativas al exequátur, no producen efectos internacionales.

Bajo estos mismos postulados se guía la sentencia dictada por la Corte de Casación francesa en la causa Société PT Putrabali Adyamulia v/ société Rena Holding et Société Mnoguta Est Epices, de 29 de junio de 2007, conocido como Putrabali ${ }^{61}$. El laudo arbitral dictado en Londres bajo las

${ }^{59}$ Corte de Casación francesa, 23 de marzo de 1994, Hilmarton c. Omnium de Traitement et de Valorisation (OTV), en XX Yearboook Commercial Arbitration, YBCA, 663, 1995; Reviue de l'Arbitrage, 994, 1994, 327.

${ }^{60}$ DAC v. Société International Bechtel Co. RG 2004/07635. Corte de Apelación de París, Sección Primera Civil, 29 de septiembre de 2005. Véase Revue de l'Arbitrage, No 695 , 2006.

${ }^{61}$ PT Putrabali Adyamulia v. Rena Holding. N ${ }^{\text {os }}$ 05-18053 y 06-13293, Corte de Casación de París, 29 de junio de 2007. Sobre el tema véase, entre otros: Clay (n. 4); Journal de Droit International, 1236, 2007; Emmanuel GaIllard, "Nota Société Putrabali Adyamulia c. S.A. 
reglas del IGPA en el año 2001, fue anulado reabriéndose la discusión y reenviada a la cuestión al tribunal arbitral, este último dictó una nueva decisión, favoreciendo a Putrabali. Recurrida la decisión que concedió el exequátur del $1^{\text {er }}$ laudo, la Corte de Casación francesa sostuvo que éste no está integrado en el ordenamiento del país sede, sino, más aún, que la sentencia arbitral no está ligada a ningún ordenamiento jurídico estatal, no tiene nacionalidad. La fuente de su juridicidad es el Derecho Internacional, cuya regularidad es examinada en el país donde se pide su reconocimiento y ejecución. De este modo, la decisión sobre la validez o invalidez del laudo que haya adoptado el juez local sobre la base del Derecho del país sede, no obliga a los jueces de otros países en los cuales aquél pretenda ser reconocido y ejecutado ${ }^{62}$. La Corte francesa concede el exequátur al laudo anulado por el tribunal inglés, argumentando, básicamente, que la CNY no establece su anulación por el tribunal judicial del país en que fue dictado como un obstáculo definitivo a la ejecución; asimismo, esta convención sienta el principio de la ley más favorable, con lo cual los tribunales franceses pueden invocar que en la ley francesa la anulación del laudo no es una causal de rechazo de ejecución.

Además, de las jurisdicciones francesas, otras Cortes también han reconocido la validez de un laudo anulado, como ocurre con las cortes federales de Estados Unidos con el caso Chromalloy Aeroservices v. Fuerza Aérea de la República Árabe de Egipto ${ }^{63}$, en el cual el laudo proferido en Egipto y anulado por las Cortes egipcias, por no haber aplicado el Derecho Administrativo egipcio, fue reconocido como ejecutable bajo la legislación de Estados Unidos, por la Corte del distrito de Columbia. La Corte sostuvo que en aplicación del principio de favorabilidad del art. vil de la CNY el laudo era susceptible de ejecución bajo el "Federal Arbitration Act". Asimismo, afirmó que no estaba obligada a reconocer el efecto de cosa juzgada a la decisión de anular el laudo de la corte egipcia y precisó que las partes habían renunciado a los recursos contra el laudo por lo que no podía la Fuerza Aérea egipcia pretender retractarse de dicho pacto ${ }^{64}$. No obstante, estas Cortes -a diferencia de la jurisdicción francesa- se han mostrado vacilantes frente a este tema ${ }^{65}$, pues sólo algunos años después, la Corte

Rena Holding et Autre", in Revue de l'Arbitrage, 697-720, 2007; Mantilla Serrano (n. 9), pp. 230-232; Rivera (n. 58).

${ }^{62}$ En esta sentencia tuvo una enorme relevancia el informe de Jean-Pierre Ancel para la Corte de Casación. Entre otros véase Julio Cesar RiverA, Arbitraje comercial. Internacional y doméstico, Buenos Aires, Lexis Nexis, 2007.

${ }^{63}$ Corte del distrito de Columbia, 1996, en Revue de l'Arbitrage, No 723, 1998.

${ }^{64}$ Mantilla Serrano (n. 32), p. 28 y ss.

${ }^{65}$ La Corte sostuvo que en aplicación del principio de favorabilidad del art. vII de la CNY el laudo era susceptible de ejecución bajo el "Federal Arbitration Act". Asimismo, 
de Apelaciones del Segundo Circuito negó el reconocimiento de un laudo dictado y anulado en su país sede (caso Baker Marine ${ }^{66}$ y Martín I. Spier ${ }^{67}$ ). Luego da un nuevo giro en el caso Pertamina ${ }^{68}$, en que la Corte manifestó de manera expresa que bajo la CNY está a la discreción del juez ejecutar un laudo arbitral cuando se encuentre pendiente una acción de anulación en el país donde fue proferido, como juez de ejecución, las Cortes gozan de discreción bajo la convención de ejecutar un laudo con independencia de que haya sido anulado en otro país, discreción que ya se ha ejercido en el pasado. Posteriormente, todo hace sostener que se ha vuelto a cambiar de parecer, pues la Corte del distrito de Columbia, en el caso Termorío ${ }^{69}$, ha negado el reconocimiento del laudo anulado en Colombia por el Consejo de $\operatorname{Estado}^{70}$. Volveremos sobre estos casos en el siguiente punto.

Más allá de esta sucinta relación de líneas jurisprudenciales basadas predominantemente en la redacción de la CNY, se esgrime como fundamento de esta tesis la desmaterialización del fuero, toda vez que el árbitro no está investido de poder por el Estado en el cual la sede se encuentra $\mathrm{y}$, por tanto, no tiene la obligación de respetar las leyes de policía o de procedimiento de dicho lugar ${ }^{71}$. El arbitraje comercial internacional debe concebirse desnacionalizado, pues no puede sostenerse que el árbitro deba obediencia a ningún orden jurídico-estatal, en tanto no tiene lex fori o la obligación de hacer respetar la ley de un Estado determinado. Su preocupación se circunscribe a velar por el respeto de la voluntad de las partes y de la comunidad internacional. El tribunal arbitral internacional resuelve un conflicto sobre un territorio y no en nombre del Estado que ejerce soberanía sobre dicho territorio, lo que plantea la inquietud de saber el por qué existen recursos contra el laudo arbitral en el Estado sede y, al mismo tiempo, un control por el Estado donde se ejecutará el fallo, que es donde se encontraría anclada su validez. A mayor abundamiento, si los árbitros no tienen fuero, los laudos tampoco tienen nacionalidad, por lo que en realidad éstos flotan y no es posible atribuir ninguna conexión con

afirmó que no estaba obligada a reconocer el efecto de cosa juzgada a la decisión de anular el laudo de la corte egipcia y precisó que las partes habían renunciado a los recursos contra el laudo por lo que no podía la Fuerza Aérea egipcia pretender retractarse de dicho pacto.

${ }_{66}$ Baker Marine Ltd. (Nigeria) v. Chevron (Nigeria) Ltd. 191 F. 3d. 194. Corte de Apelaciones para el Segundo Circuito de Estados Unidos, 199.

${ }^{67}$ Martin Spier v. Calzaturificio Tecnica SpA. 71 F. 2d. 279. Corte del distrito sur de Nueva York, 1999.

${ }^{68}$ Karaha Bodas Company, KBC v. Perusahaan Pertambangan Minyak Dan Gas Bumi Negara. Corte de Apelaciones para el Quinto Circuito de Estados Unidos, 2003.

${ }^{69}$ Termorío and Lease Co. v. Electrificadora del Atlático, Electranta. Caso N. 1:03CV02 5887. Corte Federal del distrito de Columbia, 17 de marzo de 2007.

${ }^{70}$ En una decisión muy cuestionada. Véase Mantilla Serrano (n. 32), p. 31.

${ }^{71}$ Clay (n. 9), p. 195. 
un derecho nacional ${ }^{72}$. En este entendido, no es más que un acto privado como lo es un contrato ${ }^{73}$, de manera tal que únicamente habría de recurrirse a las cláusulas contractuales y al propio criterio del tribunal arbitral. Como prueba de lo anterior se esgrime el hecho de que algunas legislaciones han permitido la renuncia del recurso de nulidad por voluntad de las $\operatorname{partes}^{74} \mathrm{O}$ la posibilidad de acudir a un tribunal distinto al de la sede arbitral ${ }^{75}$.

\section{B. La defensa de la localización}

Para este sector es una realidad ineludible que el arbitraje debe practicarse en algún lugar ${ }^{76}$ y esta elección supone consecuencias cruciales para el desarrollo del mismo y para la propia viabilidad del laudo, por lo que va mucho más allá de la ubicación física en que se llevará a cabo ${ }^{77}$. Entre los aspectos relevantes destaca la determinación de las normas de base que van a regir la validez de lo actuado por los árbitros, la regulación de las relaciones entre éstos y los jueces para conocer las cuestiones relativas al apoyo y control del arbitraje; y en cuanto rige las normas procedimentales ${ }^{78}$. Por otra

${ }^{72}$ Los laudos flotantes son aquéllos por los que mediante una manifestación de voluntad de las partes realizada en el acuerdo arbitral, se desliga o desprende -o se intenta hacerlode toda ley nacional a fin de permitir que la controversia planteada sea resuelta por los árbitros sin basarse en una ley estatal. Sobre el tema, véase, entre otros: J. PAulsson, "Delocalization of International Commercial Arbitration: When And Why It Matters", in International and Comparative Law Quarterly, No 33, 1983, pp. 53-61; SANTOS BELANDro (n. 2), pp. 28-38; José Carlos Fernández Rozas, Tratado de arbitraje comercial en América Latina, Madrid, Iustel, 2008, pp. 1.190-1.195.

${ }^{73}$ Véase James GraHAM, "Grundlegung y lex contractus en los contratos estatales”, en Revista Latinoamericana de Mediación y Arbitraje, № 18, 2001.

${ }^{74}$ Bélgica, pese a que fue el primer país en abolir el recurso de nulidad cuando ninguna de las partes tuviese vínculos jurídicos con dicho país, luego reintrodujo el recurso (1998). El nuevo art. 1717.4 del Código Judiciario establece de jure el recurso de nulidad, pero permite a las partes su renuncia si ninguna tiene vínculos con dicho país. Asimismo, el art. 192.2 de la Ley de Derecho Internacional Privado suizo también permite la exclusión del recurso de nulidad, bajo el mismo postulado antes señalado.

${ }^{75}$ Tema que puede apreciarse principalmente en materias de nombres de dominio, al realizar todo el procedimiento en línea. Véase James GraHam, "La deslocalización del arbitraje virtual”, en Revista de Derecho Informático, No40, noviembre 2001, disponible en http://www.alfa-redi.org/rdi-articulo.shtml?x=879

${ }^{76}$ Véase Philips Fouchard, Emmannuel Gaillard et B. Goldman, Traité de l'arbitrage commercial international, Litec 1996, Nº 828.

${ }^{77}$ En tal contexto Virgós Soriano (n. 14), enfatiza que el CNY 1958 otorga al país de la sede el papel de jurisdicción primaria, lo que implica que el arbitraje se rige, en principio, por dicha ley y que corresponde a los tribunales de este país la intervención en el proceso arbitral.

${ }^{78}$ Sobre el particular, véase Gary Born, Internacional Arbitration and Forum Selection Agreements: Drafting and Enforcing, The Netherlands, 2006; Carlos Espugles, M. МотA y McNerny, "Aproximación a la nueva Ley Modelo UNCITRAL sobre arbitraje comercial 
parte, el lugar del arbitraje determina el Estado en que se considera que el fallo ha sido dictado, lo que es importante para solicitar su reconocimiento o ejecución en otro Estado. Dicha determinación entraña, además, la consideración de si un arbitraje es nacional o internacional y la arbitrabilidad de una materia ${ }^{79}$.

Se sostiene que la sede no sólo provee un escenario material donde se desenvuelve el proceso arbitral, pues no se trata de un asunto de hecho, sino, principalmente, de contenido, en tanto se brindará un contexto legislativo que puede suplir la voluntad de las partes, si éstas nada han expresado sobre un punto concreto o, incluso, superponerse a ellas ${ }^{80}$. Si bien las partes tendrán un papel activo en la determinación de la ley aplicable ${ }^{81}$, no siempre tal voluntad estará clara o completa, habrá muchos puntos en que el tribunal deberá considerar en aras de mantener la eficacia del arbitraje y el laudo ${ }^{82}$. En este contexto, la legislación estatal en materia de arbitraje internacional contribuirá a reafirmar dicha autonomía en el sentido sustancial y procesal, en tanto la autorregulación, procesal y sustantiva, nace y se desarrolla al amparo de la normativa de fuente estatal ${ }^{83}$; por otro lado, suplirá los vacíos de dicha voluntad a fin de que el arbitraje prospere. En otras palabras, si las partes escogen como sede un Estado que no reconoce tal autonomía y su legislación posee un carácter impositivo, evidentemente la voluntad de 96 las partes no tendrá una gran injerencia en el arbitraje.

Bajo este postulado se considera que la ley del Estado sede por lo general aplicará sus normas procesales frente a determinados vacíos de la voluntad de las partes, cuya falta podría, incluso, provocar la nulidad del laudo $^{84}$. Por otra parte, esta ley ciertamente resolverá la problemática de

internacional", en $R C E A$., 1986, reconocían que la libertad de las partes se ve coartada por el reconocimiento de la existencia de una cierta conexión entre el procedimiento arbitral y el lugar donde éste tiene lugar, p. 13.

${ }^{79}$ Véase Fernández Rozas (n. 9).

${ }^{80}$ Véase Álvarez (n. 9), pp. 13-16.

${ }^{81}$ Es lo que se denomina como "normología", véase Bruno Oppetit, Teoría del arbitraje, traducido por Eduardo Silva Romero, Fabricio Mantilla Espinoza y José Caicedo DemouLin, Bogotá, Ed. Legis, 2006, pp. 185-186.

${ }^{82}$ Lo escrito acerca del derecho o reglas aplicables por los árbitros internacionales es abundante. Véase, a modo de ejemplo, Horacio Grigera Naón, "El derecho aplicable en el arbitraje comercial internacional”, en El contrato de arbitraje, Bogotá, Ed. Legis., 2008, pp. 607-617.

${ }^{83} \mathrm{La} \mathrm{LMU}$ y las legislaciones que la siguen contienen precisamente una arquitectura dispositiva en que la autonomía de la voluntad de las partes es respetada en el proceso arbitral.

${ }^{84} \mathrm{Si}$ bien ciertas convenciones como la convención europea sobre Arbitraje Comercial Internacional (convención de Ginebra, de 1961) omiten cualquier mención a la aplicación del procedimiento de la sede, nos encontramos con otros casos, como el de la CNY que, respecto al procedimiento a seguir en el arbitraje conserva la referencia subsidiaria al Derecho del país sede (art. v. 1, d), que prevé la posibilidad de anular el laudo cuando 
establecer qué tribunales estatales, en qué oportunidad y evento, podrán intervenir en el procedimiento arbitral. Asimismo, determinará las causales por las que el laudo podrá ser anulado, decisión que tendrá un efecto expansivo, toda vez que -en principio- un laudo anulado no podría ser ejecutado en otro lugar.

En esta línea se argumenta que la ejecutabilidad de laudos anulados ha seguido una línea diferente a la antes relatada. De hecho, sólo algunos años después de los casos vistos precedentemente, una Corte de Estados Unidos denegó el reconocimiento de los laudos dictados y anulados en Nigeria en el caso Baker Marina, en que se desestimó el argumento fundamental de Chrommalloy, basado en el artículo viI de la CNY y se concentró con exclusividad en la redacción del convenio arbitral para determinar si éste contenía una renuncia a los recursos contra el laudo. Dado que ello no ocurrió de manera expresa, se entendió que las partes se sometían a las consecuencias y vicisitudes propias de haber escogido a Nigeria como lugar de arbitraje, incluida la posibilidad de que una Corte nigeriana anulase el laudo. Esta misma situación sucedió en el caso Martin I. Spier c. Calzaturificio Technica SPA. Este laudo había sido anulado por las Cortes italianas sobre la base de que los árbitros habían fundamentado su decisión en una obligación extraña a la relación contractual sub judice. La Corte del distrito sur de Nueva York no lo reconoció en tanto ponía en entredicho la seguridad jurídica. Asimismo, el distrito de Columbia a raíz del caso Termorío negó el reconocimiento de uno anulado en Colombia por el Consejo de Estado, y otro tanto aconteció en el caso Bechtel con DAC, cuya sede de arbitraje se encontraba en Dubai ${ }^{85}$.

Por otra parte, se contrarresta el argumento del laudo flotante, en el entendido de que su validez es dispar. A favor se ha dicho que el art. v.1.d. de la CNY establece que la formación del tribunal o el procedimiento arbitral, puede constituirse y desarrollarse con arreglo a lo acordado por las partes, sin que se haga referencia a la sumisión a una ley estatal ${ }^{86}$. En contra, se ha argumentado que de acuerdo con el art. I en relación con el

el procedimiento arbitral no se ha llevado a cabo de conformidad con lo acordado por las partes o, en defecto de ese acuerdo, según lo previsto en la ley del país donde se ha efectuado el arbitraje.

${ }^{85}$ Sentencias ya singularizadas más atrás. Véase Mantilla-Serrano (n. 9), pp. 232-236.

${ }^{86} \mathrm{El}$ art. V de esta convención consagra un conjunto de causales para el rechazo del exequátur del laudo, dentro de las que no figura la posibilidad de rechazo por ser éste flotante. Finalmente, la CNY no contiene ninguna disposición expresa sobre el derecho de fondo que deberá aplicarse para la solución de la controversia. La Suprema Corte holandesa parece ser una de las pocas jurisdicciones que consideran que un arbitraje flotante se encuentra regido por la CNY al fallar el caso Bergesen contra Muller y en el caso SEE con la República Federal de Yugoslavia. 
art. v.1.a de esta convención, la validez del acuerdo arbitral debe determinarse de conformidad a la "ley a que las partes lo han sometido" y debe considerarse que:

"la sentencia no haya sido anulada o suspendida por una autoridad competente en el país en que, o conforme a cuya ley, haya sido dictada esa sentencia" ${ }^{87}$.

Asimismo, se ha entendido que con posterioridad a la entrada en vigor de la CNY, ninguna legislación nacional ha reconocido la existencia de una sentencia arbitral flotante.

Por último, se esgrime que la carencia de foro no implica prescindir por completo de una referencia estatal de una sede. El procedimiento carente de asistencia judicial produce un grado de inseguridad negativo para el desarrollo de la propia institución. Así también debe reconocerse la posibilidad que existan graves irregularidades en el comportamiento de los árbitros en el desarrollo del procedimiento, formulación de la sentencia y otros hechos que quiebren la igualdad procesal que merecen los litigantes, lo que permitiría el abuso de una de las partes, por ejemplo, sobre la base de su poder económico ${ }^{88}$, de manera que la vinculación a un orden estatal tiene cualidades positivas innegables que deben ser tenidas en cuenta a la hora de tomar la decisión correspondiente.

\section{La verdadera esencia del arbitraje:}

la coexistencia entre la autonomía

y la colaboración de los tribunales estatales

Es claro que detrás de esta profusa y compleja discusión se encuentra inmerso el papel del Estado sede en el contexto del arbitraje comercial internacional, el que se vislumbra de manera distinta, dependiendo de la filosofía que se abrigue respecto de la institución. Esta realidad nos invita a reflexionar sobre el papel de la sede en el tiempo considerando que aquél puede variar ligado a la tesis que logre predominar sobre el particular. En tal sentido, hacemos eco de las palabras pronunciadas por Bruno Oppetit,

${ }^{87}$ De este modo, la CNY impone que para que un laudo pueda ser ejecutado en otros países debe ser válido en el país de origen. La libertad concedida en materia procesal a través del art. v.1.d. se encuentra limitada por los amplios poderes concurrentes del juez de dicho Estado de origen, quien tiene la facultad de intervenir en la acción de nulidad que se instaure. Hay, pues, una sumisión que la LMU toma y refuerza en el art. 34 al restringir las causales de anulación a las mismas causales para denegar su reconocimiento o la ejecución en el Estado requerido y consignadas en el art. 36.

${ }^{88}$ En esta línea, véase SAntos Belandro (n. 72), pp. 29-31. 
en tanto si es verdad que una ideología es un discurso orientado mediante el cual una pasión busca convertirse en un valor, y las pasiones y valores son arbitrarios por no fundarse en la razón, una consecuencia capital se desprende: una ideología no puede ser ni probada ni refutada; en consecuencia, no es ni verdadera ni falsa, no puede ser otra cosas que eficaz o ineficaz, coherente o incoherente ${ }^{89}$.

Debido justamente al hecho de que la mayor cantidad de legislaciones abrigan el modelo UNCITRAL, en la actualidad no es posible sostener que la sede arbitral esté desprovista de todo valor, pues, es innegable que la LMU le confiere uno en las funciones de apoyo y control y como ley aplicable al arbitraje frente a determinadas circunstancias ${ }^{90}$, por lo que -considerando su ingerencia- no es posible pensar en que esta situación varíe mientras este tratamiento se mantenga en dicha ley.

Frente a ello cabe recordar que la CNY y la CG plantean tratamientos distintos sobre la sede. La primera parece reflejar la concepción que impregna al Derecho Internacional Privado contemporáneo, para el cual los Estados constituyen la única fuente de soberanía con exclusión de cualquier otro orden supranacional. Este instrumento fija las condiciones en las cuales cada Estado parte se compromete a reconocer en su territorio los laudos dictados en los territorios de otros Estados, reduce la importancia del papel del Estado sede y sin prohibir al Estado de la sede controlar a su manera los arbitrajes celebrados en su territorio, se concentra esencialmente en las condiciones de reconocimiento de los laudos en el ordenamiento jurídico del o de los lugares de ejecución. Como había sugerido la CCI, la sede pasa a ser un punto de conexión subsidiario, que cede al dictado de la voluntad de las partes en lo que concierne a la constitución del tribunal o del procedimiento arbitral, de manera que el incumplimiento de los requisitos del ordenamiento jurídico de la sede, en lo que se refiere a estas materias esenciales, no es sancionado en otros países. Por lo demás, las condiciones de arbitrabilidad de la controversia y de la conformidad del laudo con el orden público se aprecian a la luz de las concepciones del Estado en el que se persigue su reconocimiento y ejecución ${ }^{91}$, de manera que esta CNY se aparta de la idea de que el derecho del Estado sede es considerado fuente exclusiva de la juridicidad del laudo. En otras palabras, se invita al juez del lugar de la ejecución a razonar directamente sobre la materia constituida en el laudo, y no sobre las decisiones judiciales que hubieren podido recaer sobre él en el Estado sede.

${ }^{89}$ Bruno Oppetit, "La notion de source du droit el le droit du commerce internacional", in Archives de Philosophie du Droit. No 27, 1982, "Sources" du droit, pp. 43-44.

${ }^{90}$ Véase art. 34 de la LMU.

${ }^{91}$ Véase art. v de la CNY. 
La convención de Ginebra plantea un escenario diferente, pues, para obtener el reconocimiento o la ejecución es necesario que la sentencia se haya hecho firme en el país donde hubiere sido dictada, no considerándose como tal si es susceptible de impugnación, apelación o de recurso de casación, o si se prueba que está en curso un procedimiento para impugnar la validez de la sentencia (art. 1, línea 2, letra d). Esta diferencia de concepciones se explica porque la CG está basada en la idea que la juridicidad del laudo emana de la autorización a las partes por el soberano local para solucionar así sus controversias y la CNY rompe con ese esquema ${ }^{92}$.

Lo anterior refuerza nuestra conclusión en tanto se trata de la concepción que, en definitiva, decida acoger el legislador de un determinado Estado. Como señalamos, actualmente la mayoría de las leyes de arbitraje -siguiendo a la LMU- plantean que la determinación del lugar del mismo entraña consecuencias relevantes, así ocurre con la determinación de la ley que sustenta el procedimiento, el marco del auxilio que deben prestar los jueces estatales, la consideración de si un arbitraje es nacional o internacional, el lugar en que se considera dictado el laudo, la arbitrabilidad de la materia o el ámbito del control judicial de lo actuado por los árbitros. En este punto, es posible advertir que la lógica empleada en la configuración actual sigue la línea interpretativa según la cual la elección de la sede hace presumir la intención de las partes en cuanto a que todo vacío sea llenado o resuelto por la ley del Estado sede. Está posición, de carácter subjetivo, compartida por algunos autores como Jean Poudret y Sébastien Besson ${ }^{93}$, y entendida como el derecho de la sede del arbitraje ${ }^{94}$, es refutada por otro sector doctrinal, en el entendido que la elección de la sede presenta como única certeza que las partes han decidido acudir al arbitraje y no han optado por someter su controversia a tribunal estatal alguno ${ }^{95}$.

Por otra parte, dado que el instituto arbitral no es autónomo en su totalidad, en tanto necesita del apoyo de los tribunales estatales, es innegable que el Estado sede tendrá cierta relevancia para el éxito del arbitraje, mas la exacta trascendencia de dicho desempeño es una cuestión más amplia y

${ }^{92}$ Véase Gaillard (n. 36), pp. 37-38.

${ }^{93}$ Véase Jean Poudret y Sébastien Besson, Comparative Law of Internacional Arbitration, London, Sweet \& Maxwell, 2007, quienes pesen a no emplear términos como lex arbitri o lex fori, fundan la integralidad del régimen que rige la institución del arbitraje, incluidas la validez formal del convenio, la arbitrabilidad de la controversia, la composición del tribunal arbitral, las garantías fundamentales del proceso, la asistencia del juez estatal y el control de la regularidad del laudo, en la "loi d'arbitrage" o "lex arbitri", entendida ésta como el derecho de la sede.

${ }^{94}$ En el mismo sentido, A. Hirsch, "The Place of Arbitration and the Lex Arbitri", in The Arbitration Journal, vol. 34, No 3, september 1979, p. 43 que admite que la expresión lex arbitri es equivalente a la lex fori para la aplicación del procedimiento.

${ }^{95}$ Véase Gaillard (n. 36), p. 27. 
compleja que debe analizarse con cautela. En efecto, si bien es consustancial al arbitraje la exclusión de la jurisdicción estatal en el marco de ciertas materias y derechos ${ }^{96}$, ello no implica que los tribunales estatales queden completamente al margen de un procedimiento. Las relaciones entre los tribunales judiciales y arbitrales se desarrollan en dos dependencias diferentes de un mismo edificio ${ }^{97}$ donde el arbitraje no se presenta en ningún caso como una posición contraria a aquélla, ni como un "compartimiento estanco", al contrario, entre ambas vías de resolución de conflictos existe un amplio abanico de posibilidades ${ }^{98}$. El arbitraje requerirá de la jurisdicción estatal una cierta colaboración para el éxito de sus actuaciones provocándose la complementariedad de ambos en diferentes planos $^{99}$, de manera que arbitraje y judicatura ordinaria sólo serán excluyentes entre sí en cuanto a la competencia para conocer y resolver de una determinada materia a partir del efecto negativo del convenio arbitral.

La esencia de este mecanismo de arreglo de controversias deriva directamente del reconocimiento del Estado y del apoyo y control que éste pueda brindarle, de forma que no es factible desvincular del todo la institución arbitral de la actividad jurisdiccional; como contrapartida, debe exigirse que los jueces que intervengan en asuntos arbitrales mantengan la corrección técnica precisa y cumplan con las normas estatales para que se desarrollen con normalidad ${ }^{100}$. En otras palabras, esta institución no puede plantearse como una fórmula contra los tribunales ${ }^{101}$ ni puede pensarse en él como un cauce exclusivamente privado de resolución de conflictos, ya que la colaboración de los tribunales estatales es un punto esencial en aras

${ }^{96}$ Refiriéndose a esta temática, véase Carmen Senes Motilla, La intervención judicial en el arbitraje, Pamplona, Thomson-Civitas, 2007, p. 24.

${ }^{97}$ Tal como señala José Carlos Fernández Rozas, "Arbitraje y jurisdicción: una interacción necesaria para la realización de la justicia”, en Derecho Privado y Constitución, No 19 , 2005, p. 84, no es factible desvincular la institución arbitral de la actividad jurisdiccional del Estado y, en contrapartida, debe exigirse que los jueces que intervengan en estos asuntos mantengan la corrección técnica precisa y cumplan estrictamente con el arbitraje a fin de que éste se desarrolle con naturalidad.

${ }^{98}$ En este sentido, Verdera y Tuells (n. 9), pp. 137-177, plantea que el éxito del arbitraje depende del buen funcionamiento de la justicia y el peor enemigo del procedimiento arbitral es la eficacia de la jurisdicción. En la misma dirección, Alicia BERnARdo SAn José, Arbitraje y jurisdicción. Incompatibilidad y vías de exclusión, Granada, 2002, p. 2 y ss.

${ }^{99}$ Véase Luis Goswami, "Interim Reliefs: The role of the Courts", in Internacional Arbitration and Nacional Courts: The never ending store, ICCA International Arbitration Conference, The Hague, 2001, p. 111 y ss.

${ }^{100}$ José Carlos Fernández Rozas, La nueva ley de arbitraje, Madrid, Ed. Consejo General del Poder Judicial, Centro documentación, 2007, p. 73.

${ }^{101}$ Ricardo SANDOVAL LóPEz, "La normativa de UNCITRAL sobre arbitraje comercial internacional como instrumento de unificación", en Estudios de arbitraje, libro homenaje al Prof. Patricio Aylwin, Santiago, Editorial Jurídica de Chile, 2007, pp. 499-500. 
de la tutela pretendida y, por tanto, la coexistencia de ambos sistemas debe admitirse como necesaria e inevitable frente a determinados supuestos ${ }^{102}$. No obstante, se debe considerar como idea fundamental que esta "necesaria" intervención ${ }^{103}$ se debe plantear en los términos más restrictivos posibles, toda vez que mientras mayor es la intervención judicial en el arbitraje ${ }^{104}$, menor es la eficacia de éste último ${ }^{105}$.

Por otra parte, la idea de que el recurso de anulación no tiene ninguna virtud y debe suprimirse reservando dicho control al juez del exequátur, debe también matizarse ${ }^{106}$, pues no puede desconocerse que el control ejercido por el Estado sede presenta varias externalidades positivas. Bien entendido y ejercido, puede brindar garantías y con ello generar una mayor confianza hacia las partes. Asimismo, si éstas s no han sido claras en prever esta posibilidad, el Estado sede podría desempeñar un rol relevante al permitir una acción concreta a estos efectos ${ }^{107}$.

102 En este mismo sentido Silvia Barona (coord.), Comentarios a la ley de arbitraje (ley 60/2003, de 23 de diciembre), Barcelona, Editorial Thomson-Civitas, 2004, p. 63.

${ }^{103}$ Sobre la forma y casos en que un tribunal local puede intervenir en relación con un arbitraje internacional, véase Maitra (n. 9), pp. 239-248.

${ }^{104}$ Sobre el limitado papel, véase Goswami (n. 85), p. 114 y ss.

${ }^{105}$ El principio de intervención mínima recogido en el art. $5^{\circ}$ de la LMU, se ha extendido 102 en la generalidad de las legislaciones europeas, sólo la Arbitration Act inglesa de 1996, parece mantener una situación de control del arbitraje por parte de los jueces estatales. Comentando esta situación, véase C. Espugles Mota, "Sobre algunos desarrollos recientes del arbitraje comercial internacional en Europa", en Silvia BARONA (coord.), Arbitraje y justicia en el siglo XXI, Pamplona, Thomson Civitas, 2007, pp. 202-203.

${ }^{106}$ En esta línea, Philips Fouchard, "La portée internationale de l'annulation de la sentence arbitrale dans son pays d'origine”, en Rev. Arb., 1997, p. 239.

${ }_{107}$ Así, por ejemplo, en Francia el art. 1494 del CPCF expresa: "la convención de arbitraje puede regular el procedimiento por seguir en la instancia arbitral, directamente o por referencia a un reglamento de arbitraje; también ella puede someterlo a la ley de procedimiento que determine. En el caso de silencio de la convención, el árbitro regulará el procedimiento, en cuanto sea necesario, ya sea directamente o por referencia a una ley o a un reglamento de arbitraje". Asimismo, el art. 1493 de la referida norma dispone: "en los arbitrajes que se desarrollan en Francia o respecto de los cuales las partes han previsto la aplicación de la ley procesal francesa, la parte más diligente podrá acudir al presidente del Tribunal de Primera Instancia de París, si surge alguna dificultad en la constitución del tribunal arbitral, salvo cláusula en contrario”. Finalmente, sus arts. 1504 y 1505 establecen: "la sentencia arbitral dictada en Francia en materia de arbitraje internacional puede ser objeto de un recurso de anulación en los casos previstos en el Art. 1502 (...). El recurso de anulación previsto en el Art. 1504 se presentará ante la Corte de Apelaciones en cuya jurisdicción la sentencia ha sido dictada (...). Antes de la vigencia de este Decreto, la jurisprudencia percibía la presencia de una laguna legal al comprobar que no había normas aplicables a los arbitrajes desarrollados en Francia sometidos a un reglamento de arbitraje, por ejemplo, el de la Cámara de Comercio Internacional de París. Aún cuando la institución arbitral fuese francesa, se consideraba que no existían suficientes puntos de contacto con Francia y se les negaba todo apoyo y toda injerencia jurisdiccional. Esta posición era inconveniente para Francia en un 
Quizá el punto de conflicto resida verdaderamente en la configuración del instrumento controlador, pues el qué, quién y aplicando qué leyes, resultará crucial para establecer la perspectiva con que se aborda el instituto arbitral y la eficacia que tendrá el laudo en el contexto internacional. En nuestra opinión, la función práctica que desarrolla un Estado sede por medio del apoyo y el control debe separarse a priori de la aplicación de las leyes de dicho Estado para la validez del arbitraje, en tanto la idea de que todos los vacíos sean llenados por la ley del Estado sede y que ciertas causales del recurso de nulidad deban vislumbrarse a partir de éste último no es una idea tan lógica o convincente. Es un hecho que el arbitraje comercial internacional puede conectarse con las legislaciones de más de un Estado e, incluso, acudir a normativas transnacionales, por lo que perfectamente podríamos pensar que las leyes a aplicar podrían ser diferentes a las del Estado sede, pues todos los derechos susceptibles de tener una conexión con el arbitraje tienen en principio la misma vocación para pronunciarse sobre la validez del laudo, que es internacional por esencia. Sólo podría pensarse que ello ocurra en cuestiones concretas, en que efectivamente el Estado pudiera verse constreñido con un determinado asunto, por ejemplo, la arbitrabilidad del litigio respecto del Estado de ejecución. Volveremos sobre esta idea en las reflexiones que efectuamos al final del presente artículo.

\section{Elección de UnA SEdE ARbitral:}

DELIMITACIÓN DE LOS CRITERIOS E IMPORTANCIA DE LOS MISMOS

Dado que existen diferentes factores que influyen en un arbitraje, resulta difícil afirmar que haya un lugar único e ideal para su desarrollo en el cual todos los participantes estén cómodos ${ }^{108}$. La UNCITRAL destaca en sus notas sobre procedimiento, las siguientes:

1. Idoneidad de la ley del lugar del arbitraje en lo relativo al procedimiento;

2. La existencia de un tratado multilateral o bilateral en vigor entre el Estado en que tenga lugar el arbitraje y el Estado o los Estados

doble sentido: en primer lugar, no permitía la actuación de los órganos jurisdiccionales en relación a las actividades desarrolladas en el territorio francés; y desalentaba a establecer la sede de arbitraje en dicho país, lo que indudablemente provocaba perjuicios económicos. El giro del derecho positivo francés se debió, en gran medida, a dos casos: Gotaverken contra la empresa del Estado libio GNMTC (General Maritime Transport Organizations) y el caso Aksa-Norsolor, en ambos la jurisprudencia había negado la posibilidad de revisar los laudos dictados en arbitraje comercial internacional basados en la falta de conexión real y concreto con el sistema francés". Sobre el tema véase Rubén Santos Belandro, Arbitraje comercial internacional, $3^{\mathrm{a}}$ ed., México DF., Oxford, pp. 34-35.

${ }^{108}$ Véase Álvarez (n. 9), pp. 13-35. 
donde quizá haya de ejecutarse el laudo. El referente obligado en este punto es la CNY de 1958, pues a partir de su art. v se conduce a una uniformidad de soluciones en orden a la anulación de los laudos;

3. Finalmente, también cobra relevancia cuestiones concretas propias del arbitraje como es el objeto de la controversia, la proximidad de las pruebas, la facilidad y la eficacia para su desarrollo, el grado de colaboración de que dispongan los tribunales locales y la neutralidad de dicho lugar.

Siguiendo estos lineamientos, podemos diferenciar dos tipos de criterios: generales y especiales. Los primeros gozan de una aplicación indiscutible, en tanto nadie podría dudar sobre su conveniencia, entre ellos es crucial el régimen legal aplicable y la ejecutabilidad del laudo; los segundos, podrán interesar bajo determinadas circunstancias, como ocurre con los aspectos geográficos de la sede, costos involucrados, visas, instalaciones, proximidad para los testigos, entre otros ${ }^{109}$.

${ }^{109}$ Un estudio del Club Español del Arbitraje, finalizado en octubre de 2008, compara el posicionamiento de Madrid como sede de arbitraje en relación con las siete sedes más importantes del mundo: Londres, Miami, Nueva York, París, Singapur y Zurich. La 104 comparación se hizo en relación con veintidós aspectos que se consideran más relevantes a la hora de seleccionar una sede para la solución de conflictos comerciales internacionales. Entre éstos se destacan: A. Aspectos legales: acercamiento o influencia de la LMU; restricciones respecto a motivos adicionales de anulación del laudo, en tanto las sedes resultarían más atractivas si se corresponden los motivos con la LMU; país signatario del CNY sin reservas, en tanto permite la ejecución en casi todos los países del mundo y predetermina las causas tasadas por las que se puede denegar la ejecución de un laudo extranjero; actitud de los jueces respecto al arbitraje, pues las sedes con jueces con actitud favorable a ellos (a la hora de revisar su posible nulidad) y que otorguen un auxilio eficaz y rápido a éste son más tractivas; B. Aspectos institucionales: rapidez del procedimiento: que viene determinada por el plazo en que se fija en el reglamento correspondiente para la emisión del laudo, así como la posibilidad de prórrogas y por el hecho que se establezca un límite a su número. (Miami, Nueva York y Madrid, cumplirían este ítem); libertad en el nombramiento de árbitros: se tiene en cuenta la libertad en el nombramiento para las partes y la institución arbitral (en Madrid, París, Ginebra y Zurich existe libertad absoluta); revisión del laudo por la Corte arbitral: en tanto esto le otorga cierta garantía de calidad (París, Singapur y Madrid lo permiten); posibilidad de procedimiento electrónico: en tanto facilita las comunicaciones al permitir el uso de Internet (Madrid, París, Miami y Nueva York, lo contemplan); posibilidad de procedimiento abreviado: que permite la agilización del proceso al introducir plazos y prórrogas más cortos en ciertos casos (todas las sedes la posibilitan); costes administrativos del arbitraje: se consideran los costos de administración y los gastos en que se incurra; ley de arbitraje moderna que han sido actualizadas recientemente; apoyo institucional: un fuerte apoyo por parte de los poderes públicos promociona el uso del arbitraje e influye indirectamente sobre la actitud de los jueces al respecto. (en tal sentido, se destaca que desde el año 2006 el gobierno de la comunidad de Madrid desarrolla un amplio abanico de acciones encaminadas a promover el uso del arbitraje y a promocionar a Madrid como sede 
La elección que efectúan las instituciones arbitrales de las sedes resulta decisiva a estos efectos ${ }^{110}$, en tanto ponen de manifiesto ciertas preferencias sobre la base de criterios específicos, seleccionando lugares que conduzcan a laudos ejecutables. La CCI, por ejemplo, emplea una serie de criterios de selección con el objetivo de garantizar el principio de favor arbitratis, para ello no fija la sede del arbitraje en ninguno de los Estados de los que provienen las partes del litigio y fija como sede un Estado que sea parte de la CNY de 1958; toma en consideración la legislación del Estado en cuestión para establecer hasta qué punto su normatividad puede ser favorable al arbitraje, y observa la actitud de las Cortes nacionales del Estado en cuestión frente a elllos ${ }^{111}$. Las estadísticas de la CCI muestran la siguiente selección de lugares por las partes: en Europa, los lugares preferidos son París, Londres, Ginebra y Zurich ${ }^{112}$; en las Américas, el lugar preferido es Nueva York ${ }^{113}$; en Asia, los lugares preferidos son Singapur y Hong Kong ${ }^{114}$.

internacional); C. Aspectos de capital humano: prestigio de individuos y despachos en el mundo del arbitraje. Para la valoración de este ítems se ha utilizado el ranking desarrollado por la guía Chambers Global (Londres, Nueva York y París son sedes que destacan en estos aspectos); costos de abogados; costo de los árbitros: (se destaca que el costo en Madrid es por lo menos un 50\% inferior al resto de sedes comparadas); D. Aspectos económicos: Coste general de vida; Costos de alquiler de salas; Infraestructuras aeropuertarias y hoteleras. Más información, Véase http://www.promomadrid.com/archivos/CEA_Informe.pdf.

${ }^{110}$ En tal contexto, debemos considerar que la práctica de la CCI es seleccionar un país que sea neutral bajo cualquier criterio (art. 14.1 "La sede del arbitraje será fijada por la Corte a menos que las partes la hayan convenido"); la de la LCIA es elegir a Londres, a menos que las circunstancias aconsejen otra alternativa (art. 16.1 "Las partes podrán acordar por escrito la sede -o el lugar legal- de su arbitraje. En ausencia de tal acuerdo, la sede del arbitraje será Londres, salvo que la Corte de la LCIA, una vez analizadas todas las circunstancias concurrentes y después de haber dado trámite de audiencia por escrito a las partes, estime otro lugar como más apropiado para ser designado como sede del arbitraje"); la práctica de la CIRD es considerar todas las circunstancias relevantes (art. 13.1 "A falta de acuerdo de las partes, el administrador podrá determinar inicialmente el lugar del arbitraje, pero el tribunal arbitral tendrá la facultad de determinar definitivamente el lugar del arbitraje dentro de los 60 días siguientes a su constitución. Todas esas decisiones se harán tomando en cuenta los argumentos de las partes y las circunstancias del arbitraje").

${ }^{111}$ Los resultados de esta toma de decisión no han recibido un respaldo unánime, pues muchos Estados se consideran discriminados sin entender las circunstancias de su exclusión por la CCI. Sobre el tema, Fernández Rozas (n. 9), pp. 43-44,

${ }^{112}$ Véase Nassar Nagla, Sanctity of Contracts Revisited: A Study in the Theory and Practice of Long-term International Commercial Transactions, Boston-London, Dordrecht, 1995, p. 44.

${ }^{113}$ Otras ciudades que, según las estadísticas de la CCI, son frecuentemente escogidas en el continente americano son Miami, Ciudad de México, São Paulo y Buenos Aires. Véase John P. Guiton \& Scott Horton, Pointers in Drafting an International Arbitration Clause, Corp. Legal Times, 1993, p. 10.

${ }^{114}$ Harris PhIL, International Arbitration Practice: Can You Be Global Without It?, Of Counsel (enero de 2001), p. 13 (sosteniendo que Singapur, Hong Kong y Nueva York son las "principales arenas para el arbitraje") Un estudio muestra que: "un país que sanciona una 
Asimismo, se han destacado como lugares atractivos Madrid, Ciudad de México y Miami. La mayoría comparte rasgos comunes que favorecen la práctica del arbitraje. Derivado de lo anterior, se puede afirmar que existe una tendencia natural hacia la consolidación de éstas y otras sedes arbitrales, en tanto aportan una regulación atractiva a los operadores del tráfico comercial.

De manera general, se considera que una sede presenta una oferta interesante en el campo nos ocupa, a partir de la puesta en marcha tanto de tres mecanismos como de instrumentos concretos, esto es: la autonomía privada, la intervención judicial limitada y la neutralidad ${ }^{115}$. La autonomía implica que los legisladores redactan sus leyes arbitrales con una arquitectura esencialmente dispositiva, tanto en lo que se refiere al procedimiento como a la ley aplicable al fondo del asunto; la intervención judicial limitada tiene por objetivo dar certeza a las partes sobre la posible interferencia judicial, de modo que no se produzcan intervenciones inesperadas; por último, la neutralidad implica que el foro no imponga su idiosincrasia a las partes en temas cuyo contenido depende del Derecho nacional, tales como la arbitrabilidad o el orden público.

Revisaremos, a continuación, aquellos criterios que resultan relevantes en esta elección, dividiéndolos de acuerdo con las diversas perspectivas 106 insertas en: régimen legal aplicable, aspectos institucionales, papel de los tribunales estatales de la sede respectiva, aspectos económicos y otros ${ }^{116}$.

\section{Régimen legal aplicable: cercanía a la LMU como punto de partida}

En general, los Estados cambian, por razones económicas, su legislación con la finalidad de atraer arbitrajes a su territorio ${ }^{117}$ y en todos los casos la

ley nueva o modificada de arbitraje, experimenta un aumento estadísticamente significativo en el número de procedimientos de arbitraje ante la CCI realizados por acuerdo de partes en ese país. Dado que los datos publicados corresponden sólo a los arbitrajes ante la CCI y no a los arbitrajes administrados por otras instituciones (o procedimientos ad hoc), estas estimaciones posiblemente reflejan el aumento mínimo que se produce”. Christopher R. Drahozal, "Regulatory Competition and the Location of International Arbitration Proceedings", in Christopher R. Drahozal \& Richard W. NAimark (eds.), Towards A Science Of International Arbitration: Collected Empirical Research, No 341, reprinted, 2005.

${ }^{115}$ Refiriéndose a esta temática, véase VIRGós Soriano (n. 14).

${ }^{116}$ El detalle de los mismos los revisaremos en la determinación de su cumplimiento por cada una de las sedes arbitrales, en la segunda parte de esta investigación.

${ }^{117}$ En el Parlamento británico se utilizaron cifras económicas para evaluar la importancia de modificar su legislación. Véase Christopher DraHOzAL, "Regulatory Competition and the Location of International Arbitration Proceedings", in International Review of Law and Economics, vol. 24, 2004, pp. 371-384. 
influencia de la Ley Modelo CNUDMI, sobre arbitraje comercial internacional en la elaboración de los textos legales nuevos ha sido decisiva ${ }^{118}$. En esta línea, se considera que un Estado que haya adoptado la referida ley modelo, incluso, con modificaciones, es un Estado poseedor de una legislación moderna en materia de arbitraje y favorable respecto de dicha institución jurídica. Sin embargo, la confirmación de que una ley está basada en la Ley Modelo es sólo un punto de partida, toda vez que existen varios países que son centros líderes en el arbitraje internacional -incluyendo a Francia, Inglaterra y Estados Unidos- cuyas legislaciones son pro-arbitraje que no están basadas en la Ley Modelo de la CNUDMI de manera fidedigna como, asimismo, hay países que pese a haber adoptado la Ley Modelo, plantean un número de modificaciones que no son nada inocuas, o sus Cortes no la aplican de manera consistente, de manera que tampoco se presentan como sitios atractivos. De la mano de lo anterior, es esencial considerar no sólo si un determinado país ha sancionado una ley moderna de arbitraje sino, también, el conjunto normativo o de principios que una determinada legislación contempla con carácter obligatorio que pudiera afectar la elección legislativa realizada por las partes, así como la interpretación efectuada sobre la misma.

En este contexto, es evidente que las partes intentarán conducir el arbitraje hacia aquellas sedes donde sus leyes procesales sean proclives a la eficacia de éste y se asegure que los tribunales estatales se encontrarán dispuestos a asistirlos, interfiriendo lo menos posible con el normal desenvolvimiento del procedimiento arbitral. Desde esta óptica la elección de la sede importa contar con un manto de seguridad que brinde a las partes la confianza de que podrán recurrir en ayuda de los tribunales estatales para solicitar su apoyo a partir de la dictación de medidas precautorias, desarrollo de medidas probatorias, cumplimiento del laudo no cumplido espontáneamente, entre otras; pero, más que todo, aspiran a que dichos tribunales contribuyan al impulso y no a la obstaculización del juicio de árbitros ${ }^{119}$. De esta forma, el marco legal será relevante en una serie de materias, las que por su importancia, pasamos a revisar a continuación de manera detallada.

${ }^{118}$ Horacio Grigera NAÓn, "Arbitraje comercial internacional en el mundo actual”, en Jurisprudencia Argentina, No 5998, Buenos Aires, 14 de agosto 1996, pp. 34-35.

${ }^{119}$ A modo de ejemplo, la CCI emplea una serie criterios de selección de la sede con la finalidad de garantizar el favor arbitratis. Entre ellos toma en consideración la neutralidad del Estado, que éste se haya adherido a los convenios internacionales más relevantes (por ejemplo la CNY), analiza el estado de su legislación y la adopción de los principios básicos del arbitraje internacional, y observa también la actitud de los tribunales estatales frente al arbitraje en cuanto reconozcan cada uno de los principios señalados (competenciacompetencia, de nulidad del laudo, de intervención mínima). Sobre el particular, véase Silva Romero (n. 18), pp. 12-14; Fernández Rozas (n. 9), p. 43. 
A. Reconocimiento a la libre disposición de las partes

La legislación debe permitir a las partes establecer, según sus necesidades, aspectos tan relevantes como el convenio arbitral, persona y número de árbitros, la institución, el procedimiento arbitral, la ley de fondo aplicable a la resolución del litigio, el idioma a emplear, entre otros factores. Sólo en subsidio de dicha voluntad, la ley estatal podrá proveer una determinada solución que tienda justamente a llenar el vacío dejado por las mismas.

\section{B. Ámbito de aplicación de la ley}

Usualmente, la ley del lugar del arbitraje determinará su propio campo de aplicación el que será interpretado y aplicado por las Cortes locales, así, por ejemplo, la LMU plantea una aplicación de carácter "comercial e internacional" ${ }^{120}$ y en cada caso presenta una enunciación de los elementos que delimitan la noción, sin entregar, normalmente, tal calificación a la disposición de las partes ${ }^{121}$. La determinación de la "internacionalidad" no es sólo un ejercicio retórico, su consecuencia es la confección y aplicación de normas específicas para este tipo de controversia conectado a más de un Estado y cuyos participantes son operadores del comercio internacional. La relevancia del carácter internacional de un arbitraje se acrecienta debido a que, en algunos sistemas, la legislación aplicable difiere de la aplicable 108 al arbitraje interno que suele ser más inflexible en la materia al establecer mayores restricciones; de este modo, la internacionalidad se concibe en muchos casos como la remoción de obstáculos al desarrollo del arbitraje,

${ }^{120}$ Por lo general, la ley supletoria que se aplicará será la de arbitraje comercial doméstico, que frecuentemente resulta muy diferente al régimen aplicable a los casos comerciales internacionales. Por ejemplo, en los asuntos en que la ley local exige la constitución de una subsidiaria local, un Joint venture u otra entidad legal, como un vehículo de inversión o para permitir un tipo particular de transacción, será importante saber cómo el derecho doméstico de arbitraje define una controversia surgida entre una de estas entidades y otra parte del Estado local.

${ }^{121}$ La importancia de este tema puede apreciarse en la decisión de la Corte Suprema de British Columbia (Canadá) en Estados Unidos de México v. Metaclad Corporation. En este caso, el demandante argumentó que como el asunto versaba entre un Estado y una entidad privada se trataba de un arbitraje mixto que no podía ser clasificado como "comercial". Se señaló que como éste surgió de una actividad regulada por el Estado no podía existir una controversia comercial. Esta posición tenía como propósito excluir la aplicación de la ley de arbitraje comercial internacional de British Columbia que incluye las causales para la revisión de los laudos de la LMU. La Corte rechazó el argumento mexicano al señalar que el punto importante que debía ser considerado era la determinación de la relación primaria de la inversión, de manera que la subsume en la actividad comercial. Con todo, otras decisiones recientes de tribunales constituidos de acuerdo con el capítulo 11 del TLCAN dan cuenta que el debate subsiste. Véase Álvarez (n. 9), pp. 18-19. 
cuyos límites se encontrarán en la noción de $\operatorname{arbitrabilidad~}^{122}$ y de orden público que cada Estado acuñe al respecto.

En relación con este tema cabe advertir que cada legislación tiene criterios de definición propios y no coincidentes entre sí, por lo que seguramente este dato no resultará baladí para las partes que pretenden someterse a un arbitraje internacional. Así, por ejemplo, la convención de Ginebra establece que sus normas se aplicarán a los litigios nacidos o por nacer en operaciones del comercio internacional entre sociedades que tengan una sede social en Estados contratantes diferentes entre sí (art. 1); en otros casos se requiere que un arbitraje no presente ningún contacto con el Estado (Reino Unido, arts. 3 y 4 Arbitrion Act, 1979); para otros, basta con que uno de los participantes no tenga su residencia, domicilio o sede social o no realice operaciones en ese territorio (ley belga, 1985; ley federal Suiza, 1987, capítulo 12); algunos combinan criterios como el lugar de ejecución del laudo y la residencia (ley italiana 1994, que reforma al $C P C$ y establece la internacionalidad del arbitraje bastando que una de las partes no resida en Italia o que una parte esencial del laudo sea ejecutada en el extranjero, art. 832); otros definen la internacionalidad del asunto ubicando el elemento de extranjería en el litigio en todos los casos, y nunca en el arbitraje en sí (art. 1492 del NCPC francés); la relación jurídica de la que dimane la controversia suele ser otro criterio utilizado a estos efectos en tanto afecte los intereses del comercio internacional (art. 3.1. Ley 60/2003, España) e, incluso, algunos han adoptado el criterio de la internacionalidad subjetiva contenido en el art. 1.2, c de la LMU, que considera internacional al arbitraje

"si las partes han convenido expresamente en que la cuestión objeto del acuerdo de arbitraje está relacionada con más de un Estado" $\left(\text { art. } 1^{\mathrm{O}} \text { de la LACI }\right)^{123}$.

Más allá de ello la determinación de la internacionalidad no debiera implicar establecer diferencias ostensibles entre el arbitraje interno y el internacional. De hecho, en muchos casos se valora positivamente que el sistema legal contemple una legislación uniforme en relación con ambos tipos de arbitrajes, en tanto con ello se resguarda la utilización de criterios

${ }^{122}$ Nuria BouzA, "La arbitrabilidad de los litigios en la encrucijada de la competencia judicial internacional y de la competencia arbitral”, en REDI, vol. II, 2000, pp. 371-393.

${ }^{123} \mathrm{La}$ CNY es particularmente expresiva, pues, aunque declara aplicable al reconocimiento de laudos arbitrales dictados fuera del territorio del Estado en que tal reconocimiento se solicita, por vía de excepción se aplica también a los "laudos nacionales" en el Estado en que se solicita su reconocimiento y ejecución. De este modo, la convención acoge la internacionalidad en relación con la materia, con independencia del lugar en que se establezca la sede del tribunal arbitral. 
unívocos, lo que disminuye el riesgo que sean llenados los vacíos internacionales con preceptos inadecuados venidos desde un derecho doméstico, muchas veces arcaico, al mismo tiempo que aumenta las posibilidades de que los tribunales estatales tengan un nivel de comprensión global sobre el instituto arbitral, lo que facilita la interpretación y aplicación de su normativa de acuerdo con los estándares más avanzados.

La "comercialidad", por su parte, plantea el ámbito de aplicación material de la legislación respectiva. Normalmente la ley dispone que sus reglas serán aplicables a este tipo de litigios brindando una aproximación de lo que comprende la referida noción. Esto será relevante, toda vez que la delimitación de la comercialidad en sede internacional plantea por lo general parámetros más amplios que la comprensión del término en sede local ${ }^{124}$.

Asimismo, la ley del lugar puede definir su campo de aplicación en términos tales que distingan sobre la aplicación de sus disposiciones; por ejemplo, la LMU establece que con excepción de los arts. $8^{\circ}, 9^{\circ}, 35$ y 36 , sus normas se aplican únicamente si el sitio del trámite está en el territorio del Estado en cuestión, lo que equivale a sostener un requisito territorial, y sólo las cuatro disposiciones en comento se aplicarán sin tomar en cuenta la ubicación del lugar del arbitraje. En otras palabras, si el lugar escogido es el Estado en cuestión, se regirá por dicha ley, si el arbitraje es interna110 cional y comercial, pero su sede se fija en otro país, sólo serán aplicados los artículos en comento ${ }^{125}$.

\section{Flexibilidad y garantías procedimentales}

La legislación debiera determinar con precisión y claridad un procedimiento arbitral que sirva en caso que las partes se remitan a él, o no digan nada sobre el particular. En el procedimiento debiera conservarse el espíritu dispositivo de las pares, y eliminar, de ser posible, todo tipo de formalidades inútiles como, por ejemplo, la protocolización del laudo ante el notario público, la necesidad de que el árbitro tenga la nacionalidad o resida en el Estado sede, entre otras. Así también, debiera cuidar de establecer plazos relativamente cortos a los respectivos trámites con la finalidad de brindar celeridad al arbitraje.

Por otra parte, el procedimiento debiera garantizar ciertos principios como la neutralidad e independencia de los árbitros (por ejemplo, solicitar que comuniquen cualquier circunstancia que pudiere poner en duda su independencia e imparcialidad); la posibilidad de que ellos pueda adoptar

${ }^{124}$ Así, por ejemplo, la LMU, señala en un pie de página la noción de comercialidad.

${ }^{125}$ Véase Elina Mereminskaya, “Arbitraje comercial internacional”, en Mario Ramírez Necochea, Análisis crítico del Derecho internacional privado chileno, Santiago, Ed. Lexis Nexis, 2005, pp. 123-151. 
medidas cautelares ${ }^{126}$, cuya eficacia estará supeditada a la rapidez de su adopción y a su efectiva ejecución, en el evento en que las partes se resistan a acatarlas ${ }^{127}$; ampliar los plazos de corrección, aclaración y complemento del laudo; entre otros factores.

Normalmente, los requisitos de forma y contenido de los laudos arbitrales también se regirán por la ley del lugar del arbitraje, a menos que las partes acuerden otra cosa. Asimismo, los límites temporales para proferir el laudo y los requisitos para presentarlo también estarán definidos por esta ley.

\section{Intervención de los tribunales estatales}

Como revisamos más atrás, una de los mayores efectos que tiene la elección de la sede es la determinación de los tribunales estatales que por regla general intervendrán en el procedimiento arbitral en las funciones de apoyo y control.

Ambas tareas se recogen como una manera de ordenar la relación que debe tener la justicia estatal con la arbitral, con la finalidad de respetar los principios configurativos de ésta última, y que las partes tengan previa certeza de cuáles son los posibles caminos en que puede solicitarse la intervención de los órganos estatales ${ }^{128}$.

Con el objetivo de resguardar la autonomía tanto de la institución arbitral como de la labor de los árbitros, se ha instaurado internacionalmente el "Principio de intervención mínima" ${ }^{129}$. Éste importa, en primer lugar,

${ }^{126}$ Se trata de una medida ampliamente reconocida en los reglamentos de la CCI (art. 23); reglamento de la CNUDMI (art. 26); LMU (art. 17); entre otras. Estos instrumentos dejan un margen de actuación a los árbitros para decidir la forma de adopción de las medidas. Así, éstos podrán optar por emitirlas en la forma de laudos o de simples órdenes.

${ }^{127}$ Sobre la importancia de la forma en que se adopte esta decisión, Véase Nigel BlackAby, "La importancia de la forma y del alcance de la decisión arbitral para su ejecución”, en Arbitraje internacional. Tensiones actuales, pp. 184-186.

${ }^{128}$ Sobre esta materia, Véase $\mathrm{M}^{\mathrm{a}}$ Fernanda VÁsquez PALmA, “Coordinación del arbitraje y jurisdicciones especiales: una perspectiva latinoamericana”, en Revista de Arbitraje Comercial e Inversiones, vol. III, 2010 (3), pp. 766-788. Desde una óptica europea Carmen Otero GARCÍA-CASTRILlón, "Nuevas perspectivas para la regulación coordinada del arbitraje y la jurisdicción civil en la Unión Europea”, en Revista de Arbitraje Comercial y de Inversiones, vol. I, No 2, 2008, pp. 495-500.

${ }^{129} \mathrm{El}$ principio en comento se contempla en el art. $5^{\mathrm{o}}$ de la LMU. El artículo siguiente dispone, en cuanto al tribunal para el cumplimiento de determinadas funciones de asistencia y supervisión durante el arbitraje, que las funciones a que se refieren los artículos 11, 3 y 4 (nombramiento de árbitros); 13, 3 (recusación de árbitros); 14 (falta o imposibilidad en el ejercicio de las funciones de un árbitro); 16, 3 (facultad de tribunal para decidir sobre su propia competencia) y 34, 2 (acción de nulidad del laudo arbitral), serán ejercidas por el tribuna estatal que se designe. Cada Estado especificará, en este espacio, al promulgar la ley modelo, el tribunal, los tribunales o, cuando en aquéllas se la mencione, otra autoridad con competencia para el ejercicio de estas funciones. 
excluir todo poder de un sistema judicial nacional que no esté mencionado en la Ley de Arbitraje Comercial Internacional adoptada en un Estado sede, lo que resulta especialmente beneficioso para el arbitraje comercial internacional, pues, tal como lo indica la historia de la LM, el recurso de la intervención de los tribunales durante las actuaciones arbitrales a menudo sólo se utilizaba como una táctica dilatoria y constituía con mayor frecuencia un abuso de las actuaciones estatales y no una protección contra el abuso ${ }^{130}$; en segundo lugar, que tal intervención se conciba en los términos más acotados y precisos posibles.

La problemática que se conecta con esta materia, se relaciona con el nivel o grado de intervención ${ }^{131}$, y la calidad o sustancia de la misma, toda vez que, lo que consagra el principio en referencia es una intervención limitada, de manera tal que los tribunales estatales deben ejercer un control y apoyo efectivo, sin llegar a permear la esencia o autonomía del instituto arbitral.

Así, por ejemplo, los tribunales estatales no debieran nunca involucrarse en el fondo de lo debatido en el juicio arbitral, sino sólo resguardar el cumplimiento de determinados principios y garantías.

$\mathrm{Al}$ mismo tiempo, el recurso o acción existente para impugnar las resoluciones debieran ser limitadas y referidas a causales o criterios estrictos, precisamente con el objeto que la competencia de los tribunales arbitrales no sea vea perjudicada mediante la utilización de múltiples recursos que podrían emplearse para dilatar o intervenir injustificadamente el proceso arbitral.

Lo que debiera resguardar son garantías concretas, o prestar apoyo a los árbitros en aquellas facultades de las que carecen éstos últimos, como sucede con el poder de imperio.

En esta línea, el juez estatal debe limitar a cuestiones concretas que brinden eficacia y certeza al arbitraje llevado a cabo en su territorio ${ }^{132}$ y que se denominan comúnmente como funciones de apoyo y control arbitral.

${ }^{130}$ Véase Anuario de la Comisión de las Naciones Unidas para el Derecho Mercantil, vol. XVI, 1985 , p. 11 y ss.

${ }^{131}$ Para un análisis del papel de los tribunales nacionales en los procedimientos arbitrales, véase Redfern \& Hunter (n. 9), pp. 328-350; Chang Wang Sheng \& Lijun CaO, "The Role of Nacional Courts and Lex Fori in International Commercial Arbitration", in Loukas MisTELAS \& Julian D.M. Lew (eds.), Pervasive Problems in International Arbitration, 2006, p. 155.

${ }^{132}$ Rubén SAntos Belandro, "Brisas favorables de orientación estatal impulsan, a vela desplegada, el arbitraje comercial internacional en la región", en Estudios de arbitraje, pp. 561-563, ejemplificando la situación respecto de los países latinoamericanos (especialmente Argentina, Brasil, Uruguay, Perú), ha señalado que en éstos no existe una línea clara de intervención, o bien vacíos legales sobre estas materias podrán originar conflictos con las autoridades estatales de no fácil solución. Agrega que quizá el mayor problema existente aún en las legislaciones latinoamericanas sea el hecho que a pesar de que una gran mayoría de ellas aceptan como único recurso contra el laudo el de nulidad o anulación, todavía persiste un grupo importante de países que admiten otros recursos, con particular relevancia el de apelación. 


\section{a. Función de apoyo}

El juez estatal estará llamado a prestar apoyo o auxilio a las decisiones arbitrales que requieran de imperio o afecten a terceros del juicio, caso en que deberán velar por la legalidad de aquéllas, lo que significa una garantía frente al orden público general, mas no el ejercicio de funciones de control ${ }^{133}$. Los tribunales no pueden negarse a prestar la asistencia necesaria para la prosecución del arbitraje, excepto si aparece manifiesta la inexistencia prima facie del convenio ${ }^{134}$.

El juez estatal tiene por misión resguardar el respeto del acuerdo de las partes debiendo intervenir para evitar la ineficacia de un procedimiento arbitral, por ejemplo, por mala redacción del convenio, por carencia o inexistencia de la institución arbitral designada que impida la puesta en marcha del arbitraje, o porque el procedimiento acordado vulnera la igualdad de los intevinientes. Por su parte, el árbitro debiera contar con la potestad de practicar la mayoría de las actuaciones, de manera que el apoyo de los tribunales estatales tenga un perfil claramente residual ${ }^{135}$. Así, la ley de la sede representará un papel importante en relación con la resolución de algunas materias, como son: la recusación o el nombramiento de un árbitro; la práctica de ciertos medios probatorios que requieran del imperio del tribunal; la adopción de medidas cautelares, entre otras ${ }^{136}$.

${ }^{133}$ J. Burgos Ladrón de Guevara, "La intervención jurisdiccional del arbitraje”, en Vademécum de principios inspiradores del arbitraje y de práctica arbitral de tribunales arbitrales según la nueva ley de arbitraje 60/2003, San Sebastián, Instituto Vasco de Derecho Procesal, 2005, p. 68.

${ }^{134}$ Así lo establece, por ejemplo, la exposición de motivos de la nueva ley de arbitraje española.

${ }^{135}$ En los países latinoamericanos, con la excepción de las legislaciones argentina y brasileña, parece existir una tendencia conducente a investir al tribunal arbitral de potestad autónoma para ordenar, sobre la base de su propia autoridad, la producción de material probatorio, la comparecencia de testigos así como de peritos, y al emisión de órdenes interlocutorias de protección, de manera semejante a lo que ocurre en Alemania (secciones 1041, 1042, 1049 y 1050 ZPO); Reino Unido (secciones 39 y 34 (1), 38(2), y 41 del UK Arbitration Act); España (arts. 23 y 32) y Estados Unidos (sección 7 del Federal Arbitration Act). Así ocurre en Chile (art. 27 de la LA); Colombia (art. 152 del D. 1818/98); Ecuador (art. 22 de la ley de arbitraje, así como los artículos 211 al 245 del $C P C$, los cuales complementan la ley de arbitraje); Venezuela (art. 26). En todos estos países los árbitros gozan de potestad para actuar sin tener que invocar o solicitar la intervención del orden local para legitimar sus acciones. Comentando esta situación, Véase Paolo Di Rosa - Rafael Cox-Alomar, "El control judicial del arbitraje: ¿̇siempre tributario de un foro local?”, en Arbitraje internacional. Tensiones actuales, Bogotá, Editorial Legis, 2007, pp. 248-249.

${ }^{136}$ En tal contexto, se debe tener claro si esa normativa permite ordenar medidas cautelares a los tribunales arbitrales, a las cortes estatales o a ambos, y regular el ejercicio de esta facultad, teniendo en cuenta que una legislación estatal resultará atractiva precisamente cuando permita a los árbitros adoptar medidas cautelares y ellas cuenten con el apoyo de la justicia estatal en cuanto a su ejecución, sin vincularse en el fondo del asunto. 
También es relevante el papel que desempeñarán estos tribunales ante la alegación de una excepción de incompetencia. $\mathrm{Al}$ respecto, cabe recordar que el art. 16 de la LMU contempla el principio "Kompetenz-Kompetenz" según el cual será al propio tribunal arbitral al que le corresponderá pronunciarse sobre esta materia. El tribunal estatal debiera remitir las partes a un arbitraje a solicitud de cualquiera de ellas a más tardar en el momento de presentar el primer escrito sobre el fondo del litigio, a menos que el convenio es nulo, ineficaz o de ejecución imposible ${ }^{137}$. Finalmente, se encuentran el desarrollo de las anti-suit injunctions, o exhortaciones antiarbitraje, en tanto importan un intento de interrupción a un procedimiento arbitral por medio de prohibiciones judiciales, que son tomadas en la mayoría de los casos en el país en que se encuentra la sede del tribunal arbitral.

\section{b. Función de control}

Este punto resulta crucial para la elección de la sede, toda vez que debe determinarse si la legislación contempla recursos en contra del laudo, y en su caso, qué tipos, bajo qué causales y procedimiento, incluyendo ciertamente al tribunal que le corresponderá conocer de éstos, los límites temporales destinados al efecto, consecuencias y posibles remedios. Al mismo tiempo, conviene saber cómo los tribunales del país tienden a 114 interpretar estas causales.

Existe una tendencia en aras de privilegiar aquellas sedes en que se conciba una regulación que dé seguridad y confianza, lo que se traduce en acciones con causales limitadas, en que no intervenga más allá de lo estrictamente necesario la ley de la propia $\operatorname{sede}^{138}$. La evidencia de un control judicial excesivo provoca que las partes desistan de elegir una determinada sede arbitral. Frente a ello, es relevante que el Estado sede asuma que no debe perjudicar impropiamente la eficacia del arbitraje, de manera que los recursos contra el laudo deben ser acotados y las causales que los hacen procedente taxativas, así como los plazos, procedimiento y órganos competentes para su conocimiento determinados con antelación ${ }^{139}$ de modo de evitar que los tribunales estatales intervengan frente a cualquier petición de las partes litigantes, lo que además podría ser calificado como una intromisión impropia al contravenir la competencia de los árbitros para conocer de dichos asuntos.

${ }^{137}$ Véase art. 8 de la LMU y in de la CNY

${ }^{138}$ Francia ha sido uno de los países que más se ha ocupado de regular este sistema, véase Yves Derains, "France as a Place for International Arbitration", in The Art of Arbitration. Liber Amicorum Pierter Sanders, Deventer, 1982, pp. 112-114.

${ }^{139}$ Así, por ejemplo, la LMU, establece un catálogo de estas causales en sus arts. 34 y 36 y lo mismo acontece con el CNY. 
Asimismo, debe comprenderse que este recurso no entrega a los tribunales estatales una segunda instancia, no es factible discutir aquí cuestiones tales como la valoración de la prueba o la interpretación de las normas jurídicas aplicables. Debe tratarse de un instrumento fiscalizador del cumplimiento de las garantías procesales que en modo alguno puede entrar en el fondo de las cuestiones resueltas por los árbitros ${ }^{140}$, de lo contrario, se desnaturalizaría el instituto arbitral. En otras palabras, el juez estatal no puede modificar el fallo sino solo pronunciarse sobre algunas de las causales contempladas legislativamente para anularlo ${ }^{141}$.

En cuanto al tipo de control existe una opinión minimalista que aboga por la efectividad y concreción en aras de comprobar si se aplicó el derecho elegido por las partes, y una postura maximalista que postula lo contrario, es decir, respalda la supresión casi total de este control, con las únicas excepciones del fraude y la corrupción ${ }^{142}$. En ambas vertientes es posible constatar que la noción de orden público se desliga del aspecto sustantivo, para dejarlo reservado sólo a los principios y garantías procesales o derechos fundamentales que ha de respetar el árbitro en su actuar, considerando principalmente la naturaleza y objetivo de la acción de anulación que en ningún caso pretende constituirse como una segunda instancia a manos de los tribunales estatales, lo que viene a conformar que no pueden los tribunales estatales entrar a revisar el fondo de lo debatido en el juicio arbitral desde ningún punto de vista ${ }^{143}$. Por lo tanto, si las partes eligen una sede donde las Cortes sean propensas a cuestionar las decisiones de los árbitros, hostiles hacia el arbitraje internacional, parciales en contra de los extranjeros en disputas con nacionales, las partes estarán incrementando el riesgo de que su laudo no pudiera ser ejecutable en otro sitio.

${ }^{140}$ M. MANíEs, "El derecho a la segunda instancia en el proceso arbitral y la imposibilidad de revisar el laudo en cuanto al fondo del asunto", en Revista Actualidad Civil, 2001, p. 303.

${ }^{141}$ Esta cuestión no ha sido del todo pacífica. Por ejemplo, en España véase Manuel Albaladejo, "La ominosa tentativa de hacer irrecurrible el laudo de derecho; las normas debidas a aplicar", en Revista de Derecho Privado, 1990, pp. 171-186.

${ }^{142}$ Para un análisis de esta cuestión en la jurisprudencia francesa, Véase Delanoy, "Le contrôle de l'ordre publique du fond par le juge de l'annulation: trois contants, trois propositions", in Revue De l'arbitrage, 2007, pp. 177-222.

${ }^{143}$ Sobre el particular, véase, entre otros, Pedro Álvarez Sánchez de Movellán, "Algunas cuestiones sobre la anulación judicial del laudo en la Ley 60/2003, de arbitraje", en diario La Ley, N 6108, año xxv, 18 de octubre de 2004; Antonio LorCa Navarrete, "Los motivos de la denominada acción de anulación contra el laudo arbitral en la vigente ley de arbitraje", en diario La Ley, año Xxv, No 6005, 27 de abril de 2004; Juan CARDASO Palau, "Art. 41. Motivos", en J. GonzÁlez Soria (coord.), Comentarios a la nueva ley de arbitraje 60/2003, Navarra, Ed. Thomson Aranzadi, 2004, pp. 436-437; José Luis GonZÁLEZ-MonTES SÁnchez, El control judicial del arbitraje, Madrid, Ed. La Ley, 2008, pp. 27-28. 
En la práctica, la mayoría de las legislaciones contemplan esta acción ${ }^{144}$, pues su inclusión también se convierte en un factor de seguridad para las partes $^{145}$. Frente a la amplitud de recursos existentes como mecanismos de control de sentencias ${ }^{146}$, la legislación arbitral internacional tiende a delimitar tal accionar permitiendo sólo un tipo de acción con causales taxativas ${ }^{147}$, que puede deducirse en un breve plazo y ante un tribunal específico, tal como lo ha hecho la LMU. Con todo, ello no ha imposibilitado que algunas legislaciones, aun imitando a la LMU, permitan un número más amplio tanto de recursos como de causales para hacerlo posible ${ }^{148}$, lo que evidencia la existencia de diferencias ineludibles aun bajo la misma concepción. A ello debemos sumar el hecho que aun cuando una determinada legislación sea idéntica a la otra en esta materia, la interpretación que sus jueces realicen sobre este asunto podrá hacer un mundo de diferencia, principalmente al establecer el contenido de las causales atingentes a la arbitrabilidad y el orden público que cada Estado define de manera particular.

${ }^{144}$ Un caso en que el laudo no pasa directamente al control estatal, lo constituye el sistema del CIADI, aunque debe inscribirse en un contexto arbitral muy distinto al comercial: el arbitraje en materia de inversiones cuya puesta en marcha tiene un carácter eminentemente unilateral. El Centro prevé en su reglamento que el recurso de anulación se sustancie ante una comisión de anulación nombrada por la propia institución. Es el supuesto más parecido a la segunda instancia arbitral, puesto que no requiere acuerdo de las partes para nombrar y someterse a esta comisión. A petición de una de ella, la renuente al cumplimiento del laudo, el Centro abre el procedimiento de anulación.

${ }^{145}$ Una regulación estatal partidaria de esta posición se incluyó en el art. 191.1 ${ }^{\circ}$ LDIPr Suiza; y la solución belga incluida en la reforma del Cód. jud. Civ, de 1985.

${ }^{146}$ Sobre esta materia, véase, Marco Monroy CABra, "Recursos contra el laudo arbitral", en El contrato de arbitraje, Colombia, Legis, 2008, pp. 671-681

${ }^{147} \mathrm{El}$ sistema admite varias excepciones. Así, por ejemplo, dentro de los modelos que siguen la dualidad arbitraje interno-internacional, como en Francia, se observan soluciones diferenciadas. En este país existen diversos recursos especializados en razón de su objeto: contra la decisión que deniega el reconocimiento del laudo arbitral extranjero (art. 1501); contra la decisión que lo admite (art. 1502); y el recurso de nulidad en contra del laudo. Similar cosa ocurre en el ordenamiento sueco, toda vez que se distingue entre recurso de nulidad (art. 20) y de anulación (art. 21). Holanda establece dos recursos contra el laudo: el de anulación y el de revocación, y se da lugar al segundo en caso de fraude, falsificación y presentación de nuevos documentos. En el caso de la ley británica, se permite la apelación ante la High Court, cuya decisión puede ser revisada por la Court of Appeal (sección 1a); sin embargo, la propia ley impone una serie de condiciones para el ejercicio de este recurso. En el caso italiano, se establecen tres vías de impugnación: la nulidad, la revocación y la oposición de tercero (art. 827), mas, cuando se trata de un laudo internacional los dos últimos sólo pueden utilizarse cuando las partes lo convinieron (art. 838).

${ }^{148}$ Así, por ejemplo, la ley peruana 25.935 consagra un recurso de apelación y anulación, ambos son incompatibles entre sí y no pueden acumularse (art. 55); en Panamá el laudo arbitral es susceptible de nulidad y casación; En Bolivia existe la nulidad que se rige por las normas del $C P C$, mientras que el recurso de apelación se tramita ante la Corte Suprema; para Brasil, cabe la apelación de la sentencia que decide homologar o no el laudo y la nulidad por las causales establecidas en el art. 1100 del $C P C$; en Costa Rica existen los recursos de apelación y el de nulidad. Véase VÁsquez Palma (n. 9), pp. 109-174. 
El caso es que dentro de la configuración del recurso en cuestión adquiere una relevancia notable la determinación de las leyes aplicables en la revisión de las respectivas causales. En efecto, de acuerdo con el art. 34 de la LMU un laudo podría ser anulado por un tribunal estatal, normalmente sobre la base de dos conductos: petición de parte, o de oficio. En el primer caso, la parte que interpone la petición debe probar:

i) Que una de las partes en el acuerdo de arbitraje a que se refiere el art. $7^{\circ}$ estaba afectada por alguna incapacidad, o que dicho acuerdo no es válido en virtud de la ley a que las partes lo han sometido, o si nada se hubiera indicado a este respecto, en virtud de la ley del Estado que corresponda;

ii) Que no ha sido debidamente notificada de la designación de un árbitro o de las actuaciones arbitrales o no ha podido, por cualquier razón, hacer valer sus derechos o

iii) Que el laudo se refiere a una controversia no prevista en el acuerdo de arbitraje o contiene decisiones que exceden los términos del acuerdo; no obstante, si las disposiciones del laudo que se refieren a las cuestiones sometidas al arbitraje pueden separarse de las que no lo están, sólo se podrán anular estas últimas o

iv) Que la composición del tribunal arbitral o el procedimiento no se han ajustado al acuerdo de las partes, salvo que dicho convenio estuviera en conflictos con una disposición de esta ley de la que las partes no pudieran apartarse o, a falta de dicho acuerdo, que no se han ajustado a esta ley.

En el segundo, esto es, cuando el tribunal compruebe:

i) Que, según la ley del Estado correspondiente, el objeto de la controversia no es susceptible de arbitraje o

ii) Que el laudo es contrario al orden público de ese Estado.

Como se puede observar, la ley del Estado sede adquiere innegable relevancia, pues variadas materias deberán resolverse conforme a sus normas, tanto si las partes nada han señalado (acuerdo de arbitraje: art. $7^{\circ}$; composición del Tribunal Arbitral: art. 10; nombramiento y recusación de los árbitros: art. 11 y ss; actuaciones judiciales: arts. 18-27; pronunciamiento del laudo y normas aplicables al fondo del litigio: art. 28; etc.); como en todo evento (causales aplicables de oficio: si el objeto de la controversia no es susceptible de arbitraje o si el laudo es contrario al orden público de ese Estado). En ambos casos, la ley estatal adquiere protagonismo, pues normalmente es a dicha legislación a la que se recurre a estos efectos ${ }^{149}$.

${ }^{149}$ Así también lo establece la legislación chilena cuyo art. 34 de la LACI dispone que un laudo podrá ser anulado si el acuerdo arbitral no es válido en virtud de la ley que las partes lo han sometido, o si nada se hubiere indicado a este respecto, en virtud de la ley de este 
D. Tratamiento de los árbitros y su selección

Aquí subyacen varias cuestiones. En primer lugar encontramos el tema de los nombramientos, en tanto la ley del lugar del arbitraje podrá plantear algunas limitaciones ${ }^{150}$ como la nacionalidad y la profesión del árbitro dependiendo del tipo de arbitraje; asimismo, se ocupa de llenar vacíos relacionados con las posibles recusaciones e inhabilidades que puedan afectar a los árbitros. Si no existen tales normativas, las partes pueden llevarse desagradables sorpresas que, incluso, afecten la validez del laudo o la denegación del mismo. En relación con este punto, algunas leyes con miras a salvaguardar determinados principios, como son la independencia y la imparcialidad, plantean como obligación de los árbitros nombrados hacer presente -antes de aceptar el cargo- posibles causales que pudieren tener relevancia a estos efectos ${ }^{151}$. Otras leyes, en cambio, nada señalan sobre el particular ${ }^{152}$.

Es preciso considerar que el tribunal arbitral tiene ausencia de foro ${ }^{153}$. La conexión es meramente objetiva con el Estado sede, pues se encuentra desligado de toda jurisdicción nacional; el hecho de que la relación litigiosa esté vinculada con varios ordenamientos jurídicos estatales hace que ninguno de ellos pueda prevalecer frente al árbitro para regir la situación concreta, serán los intereses de las partes los que deben predominar ${ }^{154}$. Derivado de lo anterior, el tratamiento que la legislación de una sede brin118 de a los árbitros presenta una importancia crucial que se relaciona con el principio de intervención mínima ya visto, toda vez que si éstos son considerados como parte de la administración de justicia de un Estado, el nivel o grado de intervención que podrán asumir los tribunales estatales podrá ser superior a cuando se piensa que ellos son autónomos, y no pertenecen a ningún Estado en particular.

Finalmente, debemos tener en consideración que al elegir el lugar del arbitraje, las partes incrementan la posibilidad de que nacionales de dicho lugar sean seleccionados como árbitros, en tanto será relevante el cono-

Estado: (i). asimismo, el laudo podrá ser anulado si se refiere a una controversia no prevista o contiene decisiones que exceden los términos del acuerdo arbitral; (iii). si, según la ley chilena, el objeto de la controversia no es susceptible de arbitraje (b, i); si el laudo es contrario al orden público de Chile (b, ii), entre otras señala lo anterior de manera expresa.

${ }^{150}$ Existen varias leyes que aún plantean varias limitaciones, véase REDFERN Y HUNTER (n. 9), pp. 228-229.

${ }^{151}$ Véase Ley España, No 60/2003.

${ }^{152}$ Véase LMU.

${ }^{153}$ Elena Artuch Iriberri, El convenio arbitral en el arbitraje comercial internacional, Madrid, Eurolex, 1997, p. 156.

${ }^{154}$ La concepción de la naturaleza híbrida del arbitraje ayuda a concebir las características de la función arbitral y la secuela de la elección del derecho de fondo. Véase Santos Belandro (n. 2), pp. 182-183. 
cimiento del candidato del Derecho Procesal de la sede del arbitraje y la disponibilidad para celebrar audiencias en la sede arbitral.

\section{E. Reconocimiento y ejecución del laudo arbitral}

La ley del lugar del arbitraje también será importante en relación con el reconocimiento y ejecución del laudo tanto si ésta se busca en la propia sede arbitral $^{155}$, como en un tercer Estado. En este último caso se debe tomar en consideración si la sede ha asumido la $\mathrm{CNY}^{156}$, a fin de determinar las posibles causales de inejecución aplicables. Así, el art. v de la citada normativa establece una serie de causales taxativas para la denegación del reconocimiento y de la ejecución del laudo arbitral ${ }^{157}$, éstas causales pueden dividirse en dos grupos: las que pueden y deben ser probadas por el demandado y que funcionan a instancia de parte, como son: la invalidez del acuerdo, la violación del debido proceso, que el laudo haya sido dictado ultra o extra petita, la irregularidad en la constitución del tribunal arbitral, el carácter no obligatorio del laudo y al existencia de una solicitud de suspensión o anulación del mismo y, por el otro, las que pueden interponerse de oficio por el juez estatal, como la excepción de orden público y la falta de arbitrabilidad de la $\operatorname{liti}^{158}$. Al igual que en la acción de anulación, la labor del juez de ejecución queda limitada a constatar la existencia de alguna causal de rechazo, sin que pueda abrir ningún juicio sobre la actuación del árbitro, o resolver sobre el fondo del asunto; de este modo, el juez del exequátur constata, no juzga, aunque puede tener la latitud suficiente para valorar la causal de rechazo de acuerdo con su gravedad.

Cada legislación plantea un conjunto de causales por las que habrá de valorar el reconocimiento del laudo, señalando la legislación aplicable a estos efectos. $\mathrm{Al}$ respecto, la $\mathrm{CNY}$ nada señala sobre la ley que regirá la capacidad de las partes por lo que el juez deberá consultar sus normas de

${ }^{155}$ Esto no es lo frecuente, toda vez que existe la tendencia a evitar la jurisdicción local de cualquiera de las partes como lugar del arbitraje, véase Álvarez (n. 9), p. 27.

${ }^{156}$ La mayoría de los Estados que han ratificado la CNY lo han hecho bajo reserva de reciprocidad, la cual conlleva que las cortes ejecutarán, conforme a la convención, sólo aquellos laudos que hayan sido dictados en otros Estados Parte. Por ejemplo, la Reserva de Estados Unidos de América a la Ratificación de la Convención de Nueva York sobre el Reconocimiento y la Ejecución de las Sentencias Arbitrales Extranjeras (30 de setiembre de 1970) ("Los Estados Unidos de América aplicará la Convención, sobre la base de la reciprocidad, al reconocimiento y ejecución solamente de aquellos laudos dictados en el territorio de otro Estado Contratante").

${ }^{157}$ Los arts. v.1.e. y vi de la CNY reconocen la facultad de anular el laudo que tiene el juez del país en que o conforme a cuya ley ha sido dictada esa sentencia. La CNY no especifica cuáles son estas causales de anulación -a diferencia de la convención Europea sobre Arbitraje Comercial internacional de 1961-, por lo que queda abierta la posibilidad de que el demandado pueda atacar la sentencia por otros motivos que los enumerados en el art. v antes señalado.

${ }^{158}$ Para un estudio detallado de estas causales, véase SANTos Belandro (n. 2), pp. 86-122. 
Derecho Internacional Privado y establecer si la capacidad de aquéllas se habrá de regular por la ley de la nacionalidad de las partes, por la del domicilio o su residencia, o por la ley del acto, si nada han señalado las partes sobre la materia ${ }^{159}$. Por su parte, el art. 35 de la LMU, siguiendo a la CNY, dispone que un laudo arbitral, cualquiera que sea el país en que se haya dictado, será reconocido como vinculante y tras la presentación de una petición por escrito al tribunal competente será ejecutado en conformidad con las disposiciones de este artículo y las del artículo 36. Esta disposición señala causales muy similares a las señaladas en la CNY y a las provistas para anular el laudo en el Estado sede ${ }^{160}$, de manera tal que podríamos extrapolar a estos efectos los mismos comentarios que antes formulamos en relación con la nulidad del laudo, toda vez que la ley del Estado sede tendrá un papel relevante para el arbitraje en silencio de las partes.

Con todo, es preciso tener presente que los motivos para denegar el reconocimiento o la ejecución de un laudo sólo son válidos y eficaces en el Estado o Estados en los que la parte vencedora pretenda su reconocimiento y ejecución, en tanto los motivos de nulidad tienen repercusiones más amplias que impiden respecto de todos los demás Estados su ejecución ${ }^{161}$.

${ }^{159}$ La norma que tendrá por función determinar la ley sustantiva será entonces la del juez del exequátur por ello se ha señalado que habría sido más provechoso que la propia convención hubiera establecido una regla de conflicto de leyes uniforme. En la actualidad, las preferencias están divididas entre la lex patriae y la lex domicili, y en algunas legislaciones nacionales funciona la lex contractus como criterio derogatorio de cada uno de los principios generales señalados.

${ }^{160}$ Esta última disposición, estableciendo los motivos para denegar el reconocimiento o la ejecución, dispone: “1) Sólo se podrá denegar el reconocimiento o la ejecución de un laudo arbitral, cualquier que sea el país en que se haya dictado: a instancia de la parte contra la cual se invoca, si esta parte prueba ante el tribunal competente del país en que pode el reconocimiento o la ejecución: i) que una de las partes en el acuerdo de arbitraje a que se refiere el artículo $7^{\circ}$ estaba afectada por alguna incapacidad, o que dicho acuerdo no es válido en virtud de la ley a que las partes lo han sometido, o si nada se hubiera indicado a este respecto, en virtud de la ley del país en que se haya dictado el laudo; o ii) que la parte contra la cual se invoca el laudo no ha sido debidamente notificada de la designación de un árbitro o de las actuaciones arbitrales o no ha podido, por cualquiera otra razón, hacer valer sus derechos; o iii) que el laudo se refiere a una controversia en el acuerdo de arbitraje o contiene decisiones que exceden los términos del acuerdo de arbitraje; no obstante, si las disposiciones del laudo que se refieren a las cuestiones sometidas al arbitraje pueden separarse de las que no lo estás, se podrá dar reconocimiento y ejecución a las primeras; o iv) que la composición del tribunal arbitral o el procedimiento arbitral no se han ajustado al acuerdo celebrado entre las partes o, en defecto de tal acuerdo, que no se han ajustado a la ley del país en que se efectuó el arbitraje; o v) que el laudo no es aún obligatorio para las partes o ha sido anulado o suspendido por un tribunal del país en que, o conforme a cuyo derecho, ha sido dictado ese laudo; o cuando el tribunal compruebe: i) que, según la ley del Estado correspondiente, el objeto de la controversia no es susceptible de arbitraje; o ii) que el reconocimiento o la ejecución del laudo serían contrarios al orden público de ese Estado (...)”.

${ }^{161}$ Así, por ejemplo, la Corte en Minmetals Germany GMBH contra Ferco Steele Ltd., señaló: "In International comerse a party who contracts into an agreements to arbitrate 
Bajo esta realidad, cabe advertir que el juez de impugnación necesariamente tendrá vocación de dar una resolución que transcienda sus fronteras ${ }^{162}$, pues declarada la nulidad del laudo arbitral, ésta tendrá efectos para todas las legislaciones en que se pretenda reconocer y que siguen este planteamiento, a diferencia de la decisión del juez del reconocimiento que tendrá una visión de ámbito nacional, pues sus resultados afectan sólo al país en que se pretende reconocer y ejecutar la sentencia ${ }^{163}$.

\section{Aspectos institucionales}

Si las partes eligen una determinada institución arbitral como administradora del mismo, estos centros normalmente tendrán la misión de elegir la sede ${ }^{164}$, la que no siempre coincidirá con la del territorio donde aquélla tenga su asiento.

in foreing jurisdictions in bound not Orly by local arbitration procedure, but also by the supervisory jurisdiction of the courts of the SEAT of the arbitration . If the award is detective or the arbitration is defectively conduced the party who complains of the defect must in the first instance pursue such remedies as exist under the supervisory jurisdiction. That is because by his agreement to the place in question as the seat of arbitration he has agreed not only to refer all disputes to arbitration, but that the conduct of the arbitration should be subject to the particular supervisory jurisdiction. Adheence to the part of the agreement, must, in my judgment, be a cardinal policy considered by an English court considering enforcement of a foreing award", Extracto publicado en Yearbook Commercial Arbitration, vol. xxi, Va., 1999, p. 739 Véase también Baker Marine Ltd. v. Danos and Curole Marine Contractors, D. FreYer, "United States recognition and enforcement of annulled foreing arbitral awardsthe aftermath of the Crhromalloy case", in The Journal of International Arbitration, vol. $\mathrm{N}^{\mathrm{O}} 17$, 2000, p. 1. Otro ejemplo, la decision de la Corte de Primera instancia de Almelo (Holanda) en que sobre una petición de ejecutabilidad el tribunal rechazó considerar una súplica de falta de jurisdicción del panel arbitral donde el arbitraje se realizó (Inglaterra). Yearbook Commercial Arbitration, vol. xxvi, 2001, p. 827.

${ }^{162}$ Como explica Elena Artuch, es necesario recordar que se trata del plano internacional, de manera que la interpretación y calificación de los conceptos, en buena lógica, va a responder al campo en que se proyecta. Artuch Iriberri (n. 153), p. 153 y ss.

${ }^{163}$ Cuartero Rubio (n. 24), p. 26.

${ }^{164}$ A modo de ejemplo, véase Reglamento de Procedimientos de la CIAC, art. 13.1 (a falta de opción de las partes, la elección es efectuada por parte de la CIAC de manera inicial, "sin perjuicio de la facultad de los árbitros para hacerlo de manera definitiva", teniendo en cuenta "las pretensiones de las partes y las demás circunstancias del respectivo arbitraje"); Reglamento de Arbitraje de la OMPI, art. 39(a) (a falta de elección por las partes, "el lugar del arbitraje será determinado por el Centro, habida cuenta de cualquier observación formulada por las partes y de las circunstancias del arbitraje"); Reglas de Arbitraje del CAM, art. 20.1 (selección por parte de la institución); Reglamento de Arbitraje de la CANACO, art. 21.1 (selección por parte del tribunal arbitral, de acuerdo con las circunstancias del arbitraje); Reglamento de Arbitraje del CEMARC, art. 15 (fijando como sede supletoria la de la CEMARC, Buenos Aires) ; Reglamento del Tribunal de Arbitraje de la BCBA, art. 67 (Buenos Aires); Reglas del Centro de Arbitraje AmCham Perú, art. 3 (Lima). 
La madurez y desarrollo del arbitraje institucional de un Estado sede tiene innegable relevancia, pues puede ocurrir que las partes se inclinen por una determinada institución con relación a dónde se encuentra y la posibilidad que dicho lugar se convierta en la sede arbitral. En tal lineamiento, se suele valorar la reglamentación que el centro otorga al arbitraje, considerando atractivo a estos efectos aspectos tales como: la rapidez del procedimiento que viene determinada por el plazo en que se fija en el reglamento correspondiente para la emisión del laudo, así como la posibilidad de prórrogas; la libertad en el nombramiento de árbitros; la revisión del laudo por la corte arbitral; la posibilidad de procedimiento electrónico; la posibilidad de procedimiento abreviado que permite la agilización del proceso; los costos administrativos del arbitraje; entre otros.

Es pertinente, por tanto, que si un Estado pretende convertirse en una sede de arbitraje atractivo, deba poseer uno o más centros profesionales que estén en condiciones de prestar estos servicios de la forma más eficiente u óptima posible ${ }^{165}$. No en vano, los principales arbitrajes comerciales internacionales se han realizado y se realizan en Nueva York, Londres y París a partir del protagonismo de instituciones consolidadas en el panorama internacional como la AAA; la Corte Londinense de Arbitraje Internacional y la Corte Internacional de Arbitraje de la Cámara de Comercio Internacional de París.

\section{El papel que desempeñan los tribunales estatales de la sede: neutralidad, competencia y pericia}

La actitud que adopten los tribunales nacionales frente al arbitraje será muy relevante para la determinación de esta sede. Éste suele ser uno de los problemas más acusados, principalmente en relación con los países latinoamericanos que no siempre respetan los principios del arbitraje comercial internacional ${ }^{166}$. Aquí deben considerarse cuestiones prácticas como la neutralidad, la competencia y la experiencia de dichas Cortes en los procedimientos arbitrales. La neutralidad implica que la sede no imponga su propia idiosincrasia a la resolución del arbitraje, de manera que entienda el carácter internacional y flexible del mismo. Se pretende que la sede no favorezca a ninguna de las partes ${ }^{167}$, de manera que debe cuidar que no exista una predisposición a favor de los intereses de la parte que pueda estar conectada al Estado sede. En cuanto a la competencia, es relevante

${ }^{165}$ En algunos casos, es el propio gobierno el que incentiva estas características como sucede en el caso de Madrid.

${ }^{166}$ José Fernández Rozas, Ius mercatorum. Autorregulación y unificación del Derecho de los negocios transnacionales, Madrid, Iustel, 2003, pp. 130-133.

167 Véase Lavive (n. 9), pp. 23-33. 
que éstas tengan un nivel de experiencia y prestigio en la resolución de estas materias. Finalmente, en relación con el procedimiento, será importante saber si hay un acceso fácil a los tribunales o si, por el contrario, no pueden evitarse largas demoras ${ }^{168}$.

Pues bien, de acuerdo con lo visto en forma previa hemos de considerar que la formación del consentimiento, las materias susceptibles de ser objeto de arbitraje (arbitrabilidad) y la protección del orden público serán valoradas de acuerdo con la normativa del propio Estado sede, ello provoca que su lectura sea dispar por los diferentes sistemas jurídicos ${ }^{169}$, hecho que inevitablemente provoca dificultades prácticas al enfrentarse el arbitraje internacional a diferentes criterios normativos e interpretativos. Derivado de ello, es válida la pregunta, ¿tenemos tantos tipos de arbitraje como leyes que los regulan? ${ }^{170}$. Frente a la persistencia del Derecho nacional, parte de la doctrina aboga por el surgimiento de un derecho transnacional del arbitraje como consecuencia de la armonización de la regulación de éste que parece querer desembocar en una institución con vida propia e independiente, y que debe ser tenido en cuenta en este debate ${ }^{171}$.

En este camino, la jurisprudencia y las propias legislaciones más avanzadas en la materia avanzan hacia la autonomía arbitral ${ }^{172}$. Ello tiene un efecto concreto, en tanto las partes tienden a privilegiar a los Estados que asumen este ideal, al interpretar la normativa arbitral internacional en un claro contexto universal, sin contaminar sus regulaciones con el derecho doméstico. Esto implica, a grandes rasgos, que los criterios que impregnan la arbitrabilidad debieran descansar sobre variables puntuales y predecibles ${ }^{173}$ y el orden público interpretarse desde un claro enfoque internacional ${ }^{174}$.

${ }^{168}$ Comentando esta posible situación, véase Álvarez (n. 9), pp. 30-31.

${ }^{169} \mathrm{El}$ art. 1.5 de la LMU prevé: "La presente ley no afectará a ninguna otra ley de este Estado en virtud de la cual determinadas controversias no sean susceptibles de arbitraje o se puedan someter a arbitraje únicamente de conformidad con disposiciones que no sean las de la presente ley".

${ }^{170}$ Véase Mantilla Serrano (n. 9), p. 208.

${ }^{171}$ Gaillard (n. 36).

${ }^{172}$ A excepción de México, cuya regulación sobre arbitraje comercial se encuentra en el Código de Comercio y en el Código Federal de Procedimientos Civiles, los demás países que han expedido leyes en Latinoamérica en este lapso (Bolivia, Brasil, Colombia, Costa Rica, Chile, Ecuador, El Salvador, Guatemala, Honduras, Nicaragua, Panamá y Venezuela) han optado por expedir leyes autónomas y separadas de otros cuerpos normativos.

${ }^{173}$ En Latinoamérica, países como: Bolivia, Colombia, Ecuador, El Salvador, Guatemala, Honduras, Nicaragua, Panamá y Venezuela. Brasil, Costa Rica y Paraguay, se refieren a cuestiones patrimoniales disponibles, mientras que México y Chile, siguiendo la LMU presuponen la arbitrabilidad de toda cuestión comercial.

${ }^{174}$ Para una visión completa de la noción de orden público, véase Fouchard, GAILlard and Goldman (n. 9), p. 953 y ss. 


\section{Aspectos económicos}

Una sede de arbitraje podrá ser más conveniente que otra en virtud de una serie de factores que se relacionan con cuestiones de carácter económico. En efecto, los costos no son un dato menor en esta elección, entre ellos deben considerarse: la existencia y valor de los hoteles y transportes existentes en la sede, la cercanía para los testigos, costos de los documentos y abogados, clima y disponibilidad de recursos locales (tales como traductores, equipos, entre otros).

\section{Otros criterios a valorar}

Se debe considerar si existen exigencias especiales, tales como visas o permisos de trabajo para la entrada a estas sedes y cuál es su manejo temporal en las solicitudes. En este contexto, algunas jurisdicciones no permiten que abogados que no estén matriculados en el lugar del procedimiento representen a partes en arbitrajes internacionales llevados a cabo en tales jurisdicciones, sobre la base de que esto constituiría un ejercicio prohibido del Derecho.

La cultura arbitral internacional que impregna a un determinado país, 124 tanto en relación con sus tribunales estatales, preparación de los abogados y la doctrina suele ser otro factor a tener en cuenta $^{175}$.

\section{UNA REFLEXIÓN FINAL:}

El PAPEL DEl Estado SEDE Y LA AUTONOMÍA DE LA VOluntad DE LAS PARTES

1. Visto el escenario general, podemos apreciar que el régimen normativo del arbitraje comercial internacional se encuentra orientado a favorecer y proteger sus características autorregulatorias comercial internacional, que incluyen una marcada autonomía conferida a las partes para determinar una serie de materias (procedimiento arbitral, idioma, árbitros, leyes aplicables, plazos, institución administradora, entre otros), y subsidiariamente a los árbitros para hacer lo propio en relación con las normas jurídicas procesales y sustantivas que regirán la controversia sometida al procedimento. En este contexto, la elección que se realice deberá tomar en consi-

${ }^{175}$ Así, por ejemplo, la comunidad de Madrid destaca una cartera de abogados residentes con reconocida experiencia y prestigio en la materia, su elevado número de cortes y tribunales estatales con instalaciones modernas y adecuadas para el arbitraje, y el apoyo profesional que se mantiene. Véase http://www.madridarbitraje.com; www.clubarbitraje.com 
deración las aristas descritas más atrás, primordialmente, aquellas cuestiones en que la sede podrá tener injerencia para el éxito de un arbitraje y su posterior ejecutabilidad (apoyo y control). Este hecho constituye uno de los principales criterios diferenciadores a la hora de escoger una sede, pues evidentemente los países sostienen al respecto diversos marcos normativos e interpretaciones de los mismos.

2. Como evidenciamos, en la legislación respectiva suele otorgarse un papel adicional a la sede arbitral en tanto su legislación también podrá ser aplicable al arbitraje. En tal contexto, resulta inevitable preguntarse sobre el verdadero papel que debiera cumplir este régimen jurídico, toda vez que aun cuando las partes hagan uso de su derecho a elegir las leyes que estimen pertinentes, el árbitro deberá, en muchos casos, tener en consideración las normas y principios del Estado sede con la finalidad de proteger la validez y eficacia tanto del procedimiento como del laudo arbitral. No se trata de un asunto baladí, el problema puede dimensionarse con claridad cuando las normas pactadas por las partes contravengan a las del lugar del arbitraje; en tal contexto, un laudo podría ser anulado por los jueces del lugar del arbitraje al no respetar el derecho pactado por aquéllas o, precisamente, porque al acatar dicha autonomía desdeñó la aplicación de normas y principios considerados de orden público o de ineludible aplicación para el régimen jurídico de la sede: ¿qué debiera prevalecer?

3. Debemos considerar que en algunos casos no se establece una, sino dos autoridades competentes para revisar la validez del laudo. Así, por ejemplo, la CG establece una sola autoridad: la del país donde se dictó el laudo ${ }^{176}$, pero la CNY al referirse a dos clases de sentencias en su art. I (las dictadas en el extranjero y las dictadas en el propio territorio del Estado requerido, pero no consideradas nacionales por su orden jurídico), hace aparecer dos autoridades competentes: la del país en cuyo territorio se dictó el laudo, o la del país según cuya ley éste se dictó. ¿Qué sucederá si el juez del territorio donde se dictó el laudo lo considera nulo y el juez según cuya ley se dicte

${ }^{176}$ Tanto el art. $9^{\circ}$ de la CG como el art. v de la CNY otorgan competencia a los tribunales del lugar donde se dictó el laudo arbitral; no obstante, esta conexión jurisdiccional haría referencia no tanto al lugar concreto de firma del mismo, como al del país en que se ha desarrollado el procedimiento arbitral, entendida ésta como sede de arbitraje. Cada legislación opera de manera independiente en este punto, pero la mayoría lo hace entendiendo como sede donde se hubiere desarrollado el procedimiento arbitral, siguiendo a la LMU (art. $1.2^{\circ}$ ). Para un completo estudio de esta materia, véase Fouchard, GAILLARD and Goldman (n. 9), pp. 925-927. 
sostenga que es válido? Todo hace pensar que la anulación sólo valdrá si proviene del orden jurídico al cual pertenece la sentencia arbitral, cualquier anulación decretada por un juez de un país que no sea del orden jurídico al cual ésta pertenece debe considerarse irrelevante para los efectos de su reconocimiento y ejecución. Así, la CNY debiera interpretarse en el sentido de que, aun cuando existiese falta de coincidencia entre la ley y el territorio, lo que importa es el orden jurídico que rige al arbitraje ${ }^{177}$. A mayor abundamiento, debemos considerar que las convenciones internacionales y leyes estatales atribuyen cierta competencia a los jueces del foro, con el objetivo de brindar al laudo arbitral eficacia de cosa juzgada ${ }^{178}$.

4. El tema de la importancia de la sede debe comprenderse desde dos perspectivas de papeles diferenciadas: la posición que debe asumir el sistema jurídico de la sede si está en aparente contradicción con la voluntad de las partes o en silencio de la misma, y la que le corresponde asumir a este régimen jurídico en la anulación del laudo. Sobre la primera, si bien pudiera parecer un contrasentido pretender que los árbitros decidan la controversia con vulneración a las normas del país donde tiene su sede el arbitraje bajo la argumentación de sobreponer a ellas las normas elegidas por las partes, por cuanto la sede y, por tanto, sus normas, también fueron elegidas por éstas al escoger su sede ${ }^{179}$, lo cierto es que desde otra óptica podría sostenerse que la única elección que las partes formulan, en principio, es la de llevar su litigio a un arbitraje comercial internacional y retirarlo de la competencia estatal. Es muy probable que las partes no logren prever toda la legislación que abriga un determinado Estado, por lo que no sería extraño que las legislaciones elegidas por las mismas como aplicables al arbitraje puedan presentar algún grado de conflicto con la normativa particular del Estado en cuestión. En tal escenario, ¿qué debiera prevalecer?, todo hace pensar que en la búsqueda de la coherencia de todo arbitraje internacional debiera buscarse la voluntad de las partes y ella no tendrá, necesariamente, relación con la legislación del Estado sede.

5. No obstante lo anterior, en el estado actual de las legislaciones que se inspiran en la LMU, habrá que prestar atención a la legislación del Estado sede, toda vez que aquélla prevé que ciertas causales del recurso de nulidad y de denegación del reconocimiento del laudo,

177 Santos Belandro (n. 2), p. 115.

${ }^{178}$ Véase Miguel Virgós Soriano y Francisco Garcimartín Alférez, Derecho procesal civil internacional. Litigación internacional, Madrid, Civitas, 2000, p. 224 y ss.

${ }^{179}$ Sobre el tema, véase Grigera NAÓN (n. 82), p. 614. 
deben ser revisadas a partir de la normativa que rige al Estado sede en ciertos casos (arts. 34 y 36). Ello obliga al tribunal arbitral a considerar siempre algunas normas de dicho sistema a fin de que las mismas no se conviertan en un obstáculo para la validez del laudo, de lo contrario, podría ser, incluso, responsable de ello.

6. Considerando estas tesituras y en relación con el segundo planteamiento, debemos preguntarnos, ¿̇qué justifica esta intervención legislativa, sobre todo si consideramos que, en esencia, lo más probable es que el laudo sea ejecutado en otro sitio? En otras palabras, si el Estado sede es un "ave de paso" en el proceso arbitral, ¿por qué dicha normativa puede limitar sustancialmente el arbitraje pactado por las partes y esta decisión poseer efectos vinculantes para terceros Estados? La respuesta parece conducirnos a dos escenarios; por una parte, busca la protección del arbitraje, en tanto la legislación arbitral, en su intento de brindar un manto de seguridad en la viabilidad del proceso, llena con ello un vacío dejado por las partes a partir de su propia ley; por otra, busca el resguardo de su propio ordenamiento jurídico al impedir que las partes puedan ir más allá de lo previsto en sus normas de orden público. Ambas medidas son cuestionables, pues en la búsqueda de protección también podría pensarse en la aplicación de otras leyes supletorias quizá más ligadas al arbitraje en cuestión; asimismo, la protección de un determinado sistema jurídico se justifica sólo en una justa medida, mas no puede sostenerse que aquél limite la autonomía de un arbitraje, principalmente en lo relativo a materias sustantivas, si éste será luego ejecutado en otro lugar. Por ello la pregunta sobre el verdadero papel que ha de desempeñar un Estado sede debe replantearse respondiendo primero, ¿̇cuál es la finalidad de la intervención de su legislación?

7. Luego, la importancia de la sede es relativa y debe ajustarse a cuestiones concretas a fin de no mermar un principio básico de la institución como es la autonomía arbitral. Dentro de dichas relaciones, es en el control donde podemos encontrar mayores escollos en cuanto a la adecuada vinculación del Estado sede con el arbitraje, en tanto puede suceder que el laudo sea anulado por consideraciones internas del Estado sede y no con las del Derecho Internacional. En dicho escenario, la ejecución de los laudos arbitrales que han sido anulados a partir de dichas causales no parece ilógica, muy por el contrario, en tanto defiende la naturaleza del instituto arbitral y su carácter internacional.

8. Con ello no seguimos los postulados de la deslocalización, éstos no prestan mayor atención a la resolución de un tribunal estatal, 
sino que atienden primordialmente a la sentencia arbitral. En otras palabras, no es nuestra intención efectuar en esta oportunidad una apología del arbitraje deslocalizado o anacional, pero consideramos que el papel que debe cumplir el Estado sede es concreto: prestar apoyo al tribunal durante el proceso arbitral y controlar el respeto de ciertas garantías básicas del mismo, así como de la aplicación correcta de las leyes involucradas que han sido elegidas por las partes previamente; ambos, como hemos señalado, son cruciales para el éxito del arbitraje. En tal lineamiento, no se trata sólo de suprimir el recurso de nulidad o permitir su renuncia anticipada por las partes ${ }^{180}$, sino, más bien, de impedir que el Estado sede pueda imponer su propia idiosincrasia jurídica (concepción de arbitrabilidad, orden público, o nociones domésticas, en general). La sede, a través de sus legisladores y justicia estatal, debe mirar al arbitraje con un sello internacional, principalmente en aquellas causales que puede revisar de oficio.

$\mathrm{Al}$ respecto, conviene tener presente que las causales que se aprecian de oficio por el tribunal estatal en el recurso de nulidad se han suprimido por el art. $9^{\circ}$ de la $\mathrm{CG}^{181}$, sobre la base de la posibilidad latente que éstas sean controladas por el juez del exequátur, evitando duplicidades y dobles controles sobre el mismo laudo. Ciertamente, habría que preguntarse por la conveniencia de que dichas causales pervivan en la LMU si se considera que -como hemos señalado- el control de validez del laudo tiene una vocación internacional, de manera que la propia concepción estatal de estas materias pierde toda relevancia. De este modo, el asunto no reside en eliminar este control de la validez por el Estado sede, sino, más bien, en repensar las causales y leyes aplicables en que pueden fundarse estas alegaciones ${ }^{182}$.

${ }^{180}$ Que actualmente contempla la legislación de suiza (Ley Federal de Suiza sobre Derecho Internacional Privado, art. 912) y peruana (Ley General de Arbitraje del Perú, $\mathrm{N}^{\mathrm{O}} 26572$, art. 126).

${ }^{181}$ De la mano de ello se ha dicho que la CG y la CNY son complementarias, en tanto las CG regula las fases puramente arbitrales, mientras que ésta última se dedica en específico a su reconocimiento y ejecución, sobre todo si tenemos en cuenta que los países parte de la CG también lo son de la CNY Sobre el tema, véase Fernández Rozas (n. 39), pp. 27-28.

${ }^{182}$ Frente a lo anterior, conviene tener presente que el laudo arbitral posee una naturaleza especial pues, a diferencia de una sentencia jurisdiccional, no implica un acto de soberanía dictado por el poder público. Se trata de un acto emanado de personas privadas y cuyo fundamento último se encuentra en el acuerdo de las partes y no en el imperium del Estado. Esto permite plantearse hasta qué punto puede la jurisdicción estatal decidir rotundamente acerca de una resolución en la que no ha intervenido en modo alguno, sobre todo si se piensa que ese lugar o país es requerido por las partes en atención a su carácter neutral. 
9. Mientras tanto los cambios no se efectúen, el control ejercido por el Estado sede no debiera perder su objetivo garantista de la igualdad y voluntad de las partes, teniendo especial precaución a la hora de aplicar su normativa. Esta función fiscalizadora de la justicia estatal importa necesariamente el ajuste de diferentes intereses: el de las partes, el del Estado y el de los terceros; frente a ello, el juez estatal debe considerar que la vocación de este control no tiene un afán nacionalista, muy por el contrario, a diferencia del Estado en que se solicita el reconocimiento del laudo, el de control debe brindar una resolución que vele por su trascendencia ${ }^{183}$.

\section{BibLiografía}

Albaladejo, Manuel, "La ominosa tentativa de hacer irrecurrible el laudo de derecho; las normas debidas a aplicar", en Revista de Derecho Privado, 1990.

Álvarez Sánchez de Movellán, Pedro, "Algunas cuestiones sobre la anulación judicial del laudo en la Ley 60/2003, de arbitraje”, en diario La Ley, $\mathrm{N}^{\circ} 6108$, año XXv, 18 de octubre de 2004.

Álvarez, Henry, "La escogencia del lugar del arbitraje”, en Revista Internacional de Arbitraje, No 3, Bogotá, 2005.

Artuch IriberRi, Elena, El convenio arbitral en el arbitraje comercial internacional, Madrid, Eurolex, 1997.

Barona, Silvia (coord.), Comentarios a la ley de arbitraje (ley 60/2003, de 23 de diciembre), Barcelona, Ed. Thomson-Civitas, 2004.

Batiffol, Henri, Aspects philosophiques du droit internacional privé, Paris, Dalloz, 1956.

Berg, Albert Jan van den, "La aplicación de la Convención de Nueva York de 1958 a laudos no nacionales", en G. TAwil \& E. Zuleta (coords.), El Arbitraje comercial internacional. Estudio de la Convención de Nueva York con motivo de su $50^{\circ}$ Aniversario, Buenos Aires, Ed. Abeledo-Perrot, 2008.

Bernardo San José, Alicia, Arbitraje y jurisdicción. Incompatibilidad y vías de exclusión, Granada, 2002.

Blackaby, Nigel, "La importancia de la forma y del alcance de la decisión arbitral para su ejecución”, en Arbitraje internacional. Tensiones actuales.

Born, Gary, Internacional Arbitration and Forum Selection Agreements: Drafting and Enforcing, The Netherlands, 2006.

Bouza, Nuria, "La arbitrabilidad de los litigios en la encrucijada de la competencia judicial internacional y de la competencia arbitral", en REDI, vol. II, 2000.

${ }^{183}$ Sobre el particular Cuartero Rubio (n. 24), pp. pp. 26-28. 
Burgos Ladrón de Guevara, J., "La intervención jurisdiccional del arbitraje”, en Vademécum de principios inspiradores del arbitraje y de práctica arbitral de tribunales arbitrales según la nueva ley de arbitraje 60/2003, San Sebastián, Instituto Vasco de Derecho Procesal, 2005.

Cantuarias Salaverry, Fernando, "Cuestiones generales aplicables a las causales de anulación de laudos arbitrales dictados en el foro y a las causales para no reconocer y ejecutar laudos arbitrales dictados en el extranjero", en Themis, Revista de Derecho, No 50, 2005.

Cantuarias Salaverry, F., "Problemática general de la práctica del arbitraje internacional en Latinoamérica", artículo presentado en el panel "Arbitration Developments in Latin América”, New York State Bar Association, International Law and Practice Section, Santiago, nov. 2004, disponible en: http:// www.upc.edu.pe/bolson/0/0/3/33/142/FC6.doc.

Cardaso Palau, Juan, “Art. 41. Motivos”, en J. González Soria (coord.), Comentarios a la nueva ley de arbitraje 60/2003, Navarra, Editorial Thomson Aranzadi, 2004.

Clay, Thomas, "La importancia de la sede de arbitraje en el arbitraje internacional: ¿es todavía relevante?, en Fernando Mantilla-Serrano (coord.), Arbitraje internacional. Tensiones actuales, Bogotá, Editorial Legis, 2007.

Cremades, Bernardo y David CAIRns, "El arbitraje en la encrucijada entre la globalización y sus detractores", en RCEA, 2002.

Cuartero Rubio, $\mathrm{M}^{\mathrm{a}} \mathrm{V}$., El recurso de anulación contra el laudo arbitral en el arbitraje comercial internacional, Madrid, Ed. Eurolex, 1997.

Chatterjeek, C., "The Reality of the Party Autonomy Rule in International Arbitration", in Journal of International Arbitration, vol. 20, N 6, December 2003.

Delanoy, "Le contrôle de l'ordre publique du fond par le juge de l'annulation: trois contants, trois propositions", in Revue De l'arbitrage, 2007.

Derains, Yves, "France as a Place for International Arbitration", in The Art of Arbitration. Liber Amicorum Pierter Sanders, Deventer, 1982.

Di Rosa, Paolo - Rafael Cox-Alomar, "El control judicial del arbitraje: ¿ siempre tributario de un foro local?", en Arbitraje internacional. Tensiones actuales, Bogotá, Editorial Legis, 2007.

DrAHOZAL, Crhistopher, "Regulatory Competition and the Location of International Arbitration Proceedings", in International Review of Law and Economics, vol. 24, 2004.

Drahozal, Christopher R., "Regulatory Competition and the Location of International Arbitration Proceedings", in Christopher R. DRAHOZAL \& Richard W. Naimark (eds.), Towards A Science Of International Arbitration: Collected Empirical Research, $\mathrm{N}^{\mathrm{O}}$ 341, reprinted, 2005.

Espugles, Carlos, M. Mota y McNerny, "Aproximación a la nueva Ley Modelo UNCITRAL sobre arbitraje comercial internacional”, en RCEA., 1986.

Espugles Mota, C., "Sobre algunos desarrollos recientes del arbitraje comercial internacional en Europa", en Silvia BARONA (coord.), Arbitraje y justicia en el siglo XXI, Pamplona, Thomson Civitas, 2007. 
Fernández Rozas, José, Ius mercatorum. Autorregulación y unificación del Derecho de los negocios transnacionales, Madrid, Iustel, 2003.

Fernández Rozas, José Carlos, “Arbitraje y jurisdicción: una interacción necesaria para la realización de la justicia", en Derecho Privado y Constitución, No 19, 2005.

Fernández Rozas, José Carlos, "Determinación del lugar del arbitraje y consecuencias del control del laudo por el tribunal de la sede arbitral”, en Limaarbitration, $\mathrm{N}^{\mathrm{o}}$ 2, 2007.

FERnÁNdez RozAS, José Carlos, "El arbitraje comercial internacional entre la autonomía, la anacionalidad y la deslocalización”, en Revista Española de Derecho Internacional, vol. LVII, 2005.

Fernández Rozas, José Carlos, La nueva ley de arbitraje, Madrid, Ed. Consejo General del Poder Judicial, Centro documentación, 2007.

Fernández Rozas, José Carlos, Tratado de arbitraje comercial en América Latina, Madrid, Iustel, 2008.

Fouchard, Philips, "La portée internationale de l'annulation de la sentence arbitrale dans son pays d'origine", en Rev. Arb., 1997.

Fouchard, Philips, Emmanuel Gaillard, Berthold Goldman, "On International commercial arbitration", in E. Gaillards \& J. SAvage (eds.), Kluwer Law International, La Haya, 1999.

Fouchard, Philips, Emmanuel Gaillard et Berthold Goldman, Traité de l'arbitrage commercial international, Litec 1996, No 828.

Freyer, D., "United States recognition and enforcement of annulled foreing arbitral awards-the aftermath of the Crhromalloy case", in The Journal of International Arbitration, vol. No 17, 2000.

Gaillard Emmanuel, "Nota Société Putrabali Adyamulia c. S.A. Rena Holding et Autre”, en Revue de l'Arbitrage, 697-720, 2007.

GaIllard, Emmanuel, Teoría jurídica del arbitraje internacional, Asunción, Thomson Reuters, 2010.

Goldman, Berthold, "Les conflits de loi dans larbitrage internacional de droit privé", in Recueil des tours, vol. 109, 1963.

Goldman, Marvin, "El arbitraje comercial en las Américas", en Técnicas Financieras; vol. 8, mayo-junio, 1969.

Gómez Jene, Miguel, El arbitraje internacional en la Ley de Arbitraje de 2003, Madrid, Colex, 2007.

GonzÁlez-Montes Sánchez, José Luis, El control judicial del arbitraje, Madrid, Ed. La ley, 2008.

Goswami, Luis, "Interim Reliefs: The role of the Courts", in Internacional Arbitration and Nacional Courts: The never ending store, ICCA International Arbitration Conference, The Hague, 2001.

Graham, James, "Grundlegung y lex contractus en los contratos estatales”, en Revista Latinoamericana de Mediación y Arbitraje, Nº 18, 2001. 
Graham, James, "La deslocalización del arbitraje virtual", en Revista de Derecho Informático, $\mathrm{N}^{\circ} 40$, noviembre 2001, disponible en http://www.alfa-redi.org/ rdi-articulo.shtml? $x=879$

Grigera NaÓn, Horacio, "Arbitraje comercial internacional en el mundo actual”, en Jurisprudencia Argentina, No 5998, Buenos Aires, 14 de agosto 1996.

Grigera Naón, Horacio, "El derecho aplicable en el arbitraje comercial internacional", en El contrato de arbitraje, Bogotá, Ed. Legis., 2008.

Guiton, John P. \& Scott Horton, Pointers in Drafting an International Arbitration Clause, Corp. Legal Times, 1993.

Hirsch, A., "The Place of Arbitration and the Lex Arbitri", in The Arbitration Journal, vol. 34, No 3, september 1979.

Kaufmann-Kohler, "Le lieu de l'arbitrage à l'aube de la mondialisation", in Rev. Arb., 517, 1998.

Kleinheinsterkamp, Jean, Internacional Commercial Arbitration in Latin América, United States of América, Oceana Publications, Inc., 2005.

LaVive, P., "On the neutrality of the arbitrator and the place of arbitration", in Swiss Essays on International Arbitration, Lausanne, 1984.

Lavive, Pierre, "Ordre public transnacional (ou réellement internacional) et arbitrage internacional”, in Rev. Arb., 1986.

Lorca Navarrete, Antonio, "Los motivos de la denominada acción de anulación

132 contra el laudo arbitral en la vigente ley de arbitraje", en diario La Ley, año xxv, No 6005, 27 de abril de 2004.

MaItRA, Neelanjan, "Domestic Court Intervention in internacional Arbitration-The English View", in Journal of International Arbitration, vol. 23, N 3, 2006.

MANíEs, M., "El derecho a la segunda instancia en el proceso arbitral y la imposibilidad de revisar el laudo en cuanto al fondo del asunto", en Revista Actualidad Civil, 2001.

Mantilla-Serrano, Fernando, "Algunos apuntes sobre la ejecución de los laudos anulados y la Convención de Nueva York", 15 International Law, Revista Colombiana de Derecho Internacional, 2009.

Mantilla Serrano, Fernando, "La autonomía del derecho del arbitraje internacional: chacia un arbitraje realmente autónomo?, en Fernando MantILLA-SERRANO (coord.), Arbitraje internacional. Tensiones actuales, Bogotá, Editorial Legis, 2007.

Mayer, P., "Linsertion de la sentence Dans l'ordre juridique francais", in Le droit et la practique de larbitrage International en France, Deduci, 1984.

Mereminskaya, Elina, "Arbitraje comercial internacional”, en Mario Ramírez Necochea, Análisis crítico del Derecho internacional privado chileno, Santiago, Ed. Lexis Nexis, 2005.

Monroy Cabra, Marco, "Recursos contra el laudo arbitral", en El contrato de arbitraje, Colombia, Legis, 2008.

Nagla Nassar, Sanctity of Contracts Revisited: A Study in the Theory and Practice of Longterm International Commercial Transactions, Boston-London, Dordrecht, 1995. 
Oppetit, Bruno, Teoría del arbitraje, Bogotá, Legis, 2006.

Oppetit, Bruno, Teoría del arbitraje, traducido por Eduardo Silva Romero, Fabricio Mantilla Espinoza y José Caicedo DemouLin, Bogotá, Ed. Legis, 2006.

Otero García-Castrillón, Carmen, "Nuevas perspectivas para la regulación coordinada del arbitraje y la jurisdicción civil en la Unión Europea”, en Revista de Arbitraje Comercial y de Inversiones, vol. I, No 2, 2008.

Palao Moreno, Guillermo, "Nuevas tendencias en materia de arbitraje comercial internacional en América Latina”, en S. Barona Vila (Coord.), Arbitraje y justicia en el siglo XXI, Madrid, 2007.

PARK, William, "Arbitration of International Business Disputes: Studies", in Law and Practice, $\mathrm{N}^{\mathrm{O}}$ 1983, Oxford University Press, 2006.

PARK, William, "The Lex Loci Arbitri and International Commercial Arbitration", in Review International and Comparative Law Quarterly, No 32, 1983.

Pérez Pacheco, Yaritza, "Los aportes de la conferencia especializada interamericana sobre Derecho Internacional Privado en materia de arbitraje internacional”, en Boletín Mexicano de Derecho Comparado, año XLI, No 121 , enero-abril de 2008.

PAulsson, J., "Delocalization of International Commercial Arbitration: When And Why It Matters", in International and Comparative Law Quarterly, No 33, 1983.

Pereznieto, Leonel \& James Graham, "La muerte programada del Estado sede del arbitraje”, en Revista Latinoamericana de Mediación y Arbitraje, México, 2006.

Petsche, M., The growing Autonomy of International Commercial Arbitration, München, European Law Publishers, 2005.

PHIL Harris, International Arbitration Practice: Can You Be Global Without It?, Of Counsel (enero de 2001).

Poudret, Jean y Sébastien Besson, Droit Comparé de l'arbitrage internationakl Schlthess, Zurich, 2002.

Poudret, Jean y Sébastien Besson, Comparative Law of Internacional Arbitration, London, Sweet \& Maxwell, 2007

Redfern, Alan y Martin Hunter, Law and practice of International commercial arbitration, $3^{\mathrm{a}}$ ed., Londres, Sweet \& Maxwell, 1999.

Rivera, Julio Cesar, Arbitraje comercial. Internacional y doméstico, Buenos Aires, Lexis Nexis, 2007.

SANDOVAL LóPEz, Ricardo, "La normativa de UNCITRAL sobre arbitraje comercial internacional como instrumento de unificación", en Estudios de arbitraje, libro homenaje al Prof. Patricio Aylwin, Santiago, Ed. Jurídica de Chile, 2007.

Santos Belandro, Rubén, Arbitraje comercial internacional, $3^{\mathrm{a}}$ ed., México DF., Oxford.

Santos Belandro, Rubén, "Brisas favorables de orientación estatal impulsan, a vela desplegada, el arbitraje comercial internacional en la región", en Estudios de arbitraje. 
Santos Belandro, Rubén, "Se ha instalado un provechoso quid quo en los Estados Latinoamericanos respecto del arbitraje”, en Revista Vasca de Derecho Procesal y Arbitraje, tomo XVI, mayo 2004, pp. 427-433.

Senes Motilla, Carmen, La intervención judicial en el arbitraje, Pamplona, ThomsonCivitas, 2007.

Silva Romero, E., "Breves observaciones sobre la modernidad del arbitraje internacional. A propósito de la nueva ley española de arbitraje”, en Tribuna Abierta, $\mathrm{N}^{\circ}$ 9, 2004.

Siqueiros, J.L., El arbitraje comercial internacional. La experiencia latinoamericana, México, Ed. Porrúa, 1999.

Vásquez Palma, Ma Fernanda, Arbitraje en Chile. Análisis crítico de su normativa y jurisprudencia, Ed. Legal Publishing, 2009.

VÁsquez Palma, Ma Fernanda, "Coordinación del arbitraje y jurisdicciones especiales: una perspectiva latinoamericana", en Revista de Arbitraje Comercial e Inversiones, vol. III, 2010, (3).

VÁSQUez PALma, M ${ }^{\mathrm{a}}$ Fernanda, “¿Están preparados los países latinoamericanos para ser sedes de arbitrajes?”, en Revista Internacional de Arbitraje, $\mathrm{N}^{\circ} 10$, enerojunio 2009.

Verdera y Tuells, Evelio, "La elección del lugar y del idioma en el procedimiento arbitral", en RCEA, 1995.

134 Virgós Soriano, Miguel, "Arbitraje comercial internacional y Convenio de Nueva York de 1958”, en diario La Ley, año XxVII, N 6679, 2007.

Virgós Soriano, Miguel y Francisco Garcimartín AlfÉrez, Derecho procesal civil internacional. Litigación internacional, Madrid, Civitas, 2000.

WAng Sheng Chang \& Lijun CaO, "The Role of Nacional Courts and Lex Fori in International Commercial Arbitration", in Loukas Mistelas \& Julian D.M. LEw (eds.), Pervasive Problems in International Arbitration, 2006.

Zuleta Jaramillo, Eduardo, "El reconocimiento y ejecución internacionales de laudos anulados", en Cámara de Comercio de Bogotá, N 7, Bogotá, 2002. 